ISSN $2527-5542$
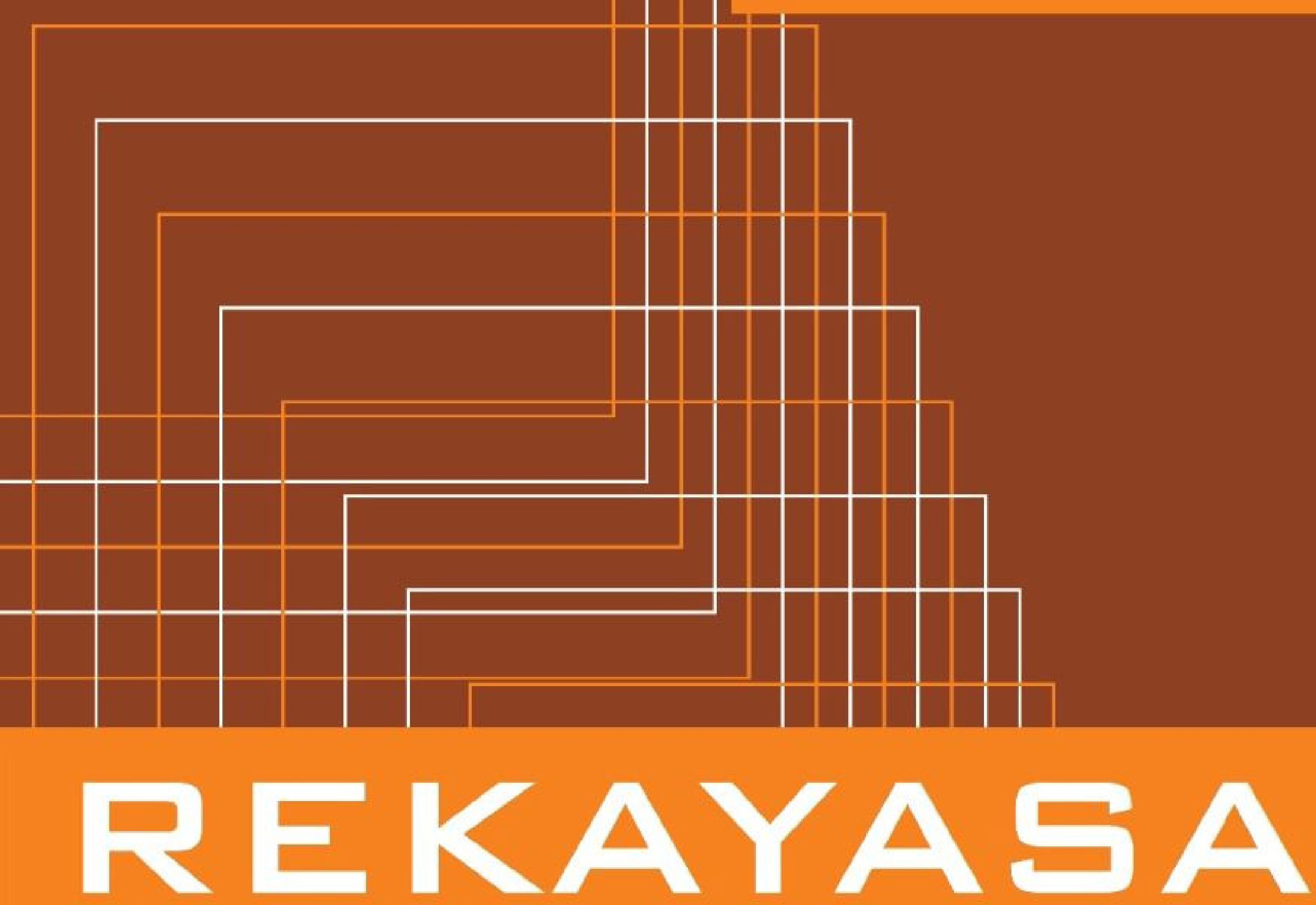
JURNAL TEKNIK SIPIL 


\section{REKAYASA TEKNIK SIPIL}

Media Publikasi Karya Ilmiah di Bidang Teknik Sipil

Volume 4, Nomer 2.

Desember 2019

\section{Penanggung Jawab :}

Ir. Moch. Hazin Mukti, MT., MM

\section{Mitra Bestari :}

Dr. Ir. Lalu Mulyadi, MT

Dr. Ir. Kustamar, MT

Dr. Ir. Subandiyah Azis, CES

Dr. Faisal Estu Yulianto, ST., MT.

Dr. Gusfan Khalik, ST., MT.

\section{Komite Pelaksana :}

Dedy Asmaroni, ST., MT.

Taurina Jemmy Irwanto, ST., MT.

Ahmad Fatoni ST., M.MT.

Ahmad Fausi, ST.

Aldi Setiawan, ST.

\section{Komite Pelaksana :}

Fakultas Teknik - Universitas Madura

Jl. Raya Panglegur KM. 3,5 Pamekasan 69317

Telp. (0324) 322231 psw 114 Fax (0324) 327418

Email : Jurnal.rekayasa.unira@gmail.com 


\section{REKAYASA TEKNIK SIPIL}

Media Publikasi Karya Ilmiah di Bidang Teknik Sipil

Volume 4, Nomer 2.

Desember 2019

\section{DAFTAR ISI}

1. Pengaruh Gaya Kepemimpinan Terhadap Budaya K3 yang Dimoderasi Tingkat Pendidikan dan Pengalaman Kerja pada Proyek Konstruksi di Surabaya Jenny Caroline, Feri Harianto, Rochman Pasik H

2. Studi Eksperimental Penambahan Serbuk Arang Kayu Dengan Kadar 10\% Terhadap Filler Semen Pada Campuran Perkerasan AC - WC Kurnia Hadi Putra, Mutiara Fidausi

3. Analisis Penerapan Sistem Manajemen K3 dan Kelengkapan Fasilitas K3 Pada Proyek Konstruksi Gedung Di Surabaya Arizal Firmansyah, Priyono, Feri Harianto

4. Analisis Pada Pekerjaan Galian Untuk Mencari Produktivitas Dan Kombinasi Alat Berat Di Proyek Pembangunan Refinery Di Pt. Salim Ivomas Pratama, Tbk.

Mauliddiyah Ainurrizki, Siti Choiriyah, Theresia MCA

5. Analisis Kinerja Operasional dan Kualitas Pelayanan PO. Mutiara Indah Murni dan PO. Widji Lestari pada Trayek Surabaya-Tuban Amrita Winaya, Theresia MCA, Bimanda Maryudi

6. Analisis Percepatan Durasi Terhadap Pekerjaan Proyek Konstruksi Time Cost Trade Off Method ( Studi Kasus : Pembangunan Gedung Dinas Perdagangan Dan Perindustrian Kabupaten Sampang )

Dedy Asmaroni, Ach Fendi 


\title{
Pengaruh Gaya Kepemimpinan Terhadap Budaya K3 yang Dimoderasi Tingkat Pendidikan dan Pengalaman Kerja pada Proyek Konstruksi di Surabaya
}

\author{
Jenny Caroline ${ }^{1}$, Feri Harianto ${ }^{2}$, Rochman Pasik $\mathrm{H}^{3}$ \\ 1,2,3 Jurusan Teknik Sipil, Fakultas Teknik Sipil dan Perencanaan, ITATS, Surabaya \\ E-mail:gokbio@yahoo.com
}

\begin{abstract}
ABSTRAK: Sikap dan perilaku pekerja merupakan gambaran nyata penerapan gaya kepemimpinan di pelaksanaan proyek konstruksi. Sikap dan perilaku pekerja adalah cerminan dari budaya K3, oleh karena itu peranan kepemimpinan sangat penting dalam membentuk budaya K3. Kepemimpinan yang sadar dan komitmen terhadap K3 harus ada dalam jiwanya, sehingga seluruh anggota perusahaan bersemangat mematuhi sistem manajemen K3, dengan demikian maka budaya K3 dapat berhasil terwujudkan. Penelitian ini bertujuan untuk mengetahui pengaruh gaya kepemimpinan terhadap budaya k3 yang dimoderasi tingkat pendidikan dan pengalaman kerja. Penelitian ini menggunakan metode survei dengan pengambilan data melalui kuesioner. Responden penelitian yaitu project manager, site manager, pengawas, dan mandor, dengan ukuran sampel 60 responden pada 6 proyek konstruksi di Surabaya. Analisis yang digunakan adalah analisis deskriptif dan analisis regresi linear sederhana dengan variabel moderarasi. Hasil penelitian ini menunjukkan bahwa gaya kepemimpinan berpengaruh positif terhadap budaya K3 ( $\alpha<5 \%$ ), sedangkan variabel moderasi tingkat pendidikan pemimpin memperlemah pengaruh gaya kepemimpinan terhadap budaya K3.
\end{abstract}

KEYWORDS : Gaya kepemimpinan, budaya K3, pengalaman kerja, tingkat pendidikan.

\section{PENDAHULUAN}

Di Inodonesia proyek konstruksi mempunyai tingkat risiko kecelakaan kerja yang tinggi, hal ini dapat terjadi karena terhambatnya pelaksanaan K3. Terhambatnya karena pimpinan proyek masih mengejar capaian kinerja keuangan jangka pendek atau profit, rendahnya tingkat kesadaran pekerja terhadap keselamatan kerja. Selain itu juga adanya kesenjangan antara kenyataan hidup dalam era teknologi tinggi yang mengandung risiko tinggi dan cara pandang manusia terhadap risiko tersebut, sehingga pimpinan dan pekerja sering mengambil keputusan dengan jalan pintas ( Gunawan,2013).

Metode dan pendekatan pelaksanaan proyek yang cenderung sesuai jadwal dan tertata rapi serta melibatkan banyak sub pekerjaan termasuk banyaknya jumlah pekerja harus diimbangi dengan pelaksanaan budaya keselamatan dan kesehatan kerja yang maksimal supaya risiko kecelakaan kerja sekecil mungkin dapat terhindarkan. Disinilah peranan penting seorang pemimpin proyek dengan gaya kepemimpinannya berperan besar terhadap kesuksesan proyek. Robbins dan Judge (2009) mendefinisikan kepemimpinan adalah kemampuan untuk mempengaruhi kelompok ke arah pencapaian visi. Gaya kepemimpinan mandor mempunyai korelasi dan pengaruh signifikan terhadap Keselamatan dan Kesehatan Kerja (K3) (Papang A \& Feri H, 2014). Berdasarkan hasil observasi singkat sikap dan perilaku pekerja pada pelaksanaan proyek konstruksi merupakan gambaran nyata penerapan gaya kepemimpinan. Hal ini menjadi tolak ukur sejauh mana penerapan budaya K3 dan sejauh mana kebijakan yang diambil untuk menerima resiko kecelakaan kerja yang akan terjadi.

Membangun budaya K3 tidak akan terlaksana bila pimpinan dari perusahaan tidak mempunyai komitmen tentang K3, selain itu budaya K3 dipengaruhi oleh sistem yang dianutnya, karena perilaku pimpinan akan menjadi pegangan tata nilai oleh para pekerja (Gunawan \& Waluyo, 2015). Sikap, perilaku, dan cara pandang pimpinan dan pekerja terhadap K3 dipengaruhi pendidikan (Notoatmojo, 2003), oleh karena itu kurangnya pengetahuan dan ketrampilan adalah salah satu potensi pengaruh terjadinya kecelakaan kerja, karena pendidikan seseorang mempengaruhi cara berfikir dalam menghadapi pekerjaannya. Proses pembentukan pengetahuan dan keterampilan dipengaruhi pendidikan dan pengalaman (Handoko, 1987; Muhammad .D.I, dkk, 2017; Notoatmojo, 2003; Asri, 1986).

Tujuan penelitian ini adalah : (1) Mengetahui pengaruh gaya kepemimpinan $(\mathrm{X})$ terhadap budaya $\mathrm{K} 3$ (2) mengetahui tingkat pendidikan (Z1) memoderasi pengaruh gaya kepemimpinan (X) terhadap budaya $\mathrm{K} 3$ (Y), (3) mengetahui pengalaman kerja (Z2) memoderasi pengaruh antara gaya kepemimpinan $(\mathrm{X})$ terhadap budaya $\mathrm{K} 3$ (Y), (4) mengetahui tingkat pendidikan (Z1) dan pengalaman kerja (Z2) memoderasi pengaruh gaya kepemimpinan $(\mathrm{X})$ terhadap budaya $\mathrm{K} 3(\mathrm{Y})$.

\section{METODE PENELITIAN}

Pengambilan sampel sebagai responden digunakan metode purpusive sampling, dengan pertimbangan (expert judgement) sesuai dengan tujuan penelitian (Solimun, 2018). Responden dalam penelitian ini adalah project manager, site manager, pengawas, pelaksana, dan mandor dengan jumlah responden 60 orang, untuk pengujian validitas dan reliabilitas kuesioner digunakan sebanyak 15 orang. Lokasi penelitian pada proyek konstruksi di Surabaya seperti pada tabel 2. Variabel bebasnya adalah gaya kepemimpinan (X) dan varibel terikaynya yaitu budaya K3 (Y), sedangkan variabel moderatornya yaitu tingkat pendidikan (Z1) dan pengalaman kerja (Z2). Adapun kerangka penelitian seperti pada gambar 1 . Pengambilan data digunakan kuesioner, dengan kisi-kisi kuesioner seperti pada tabel 1. Skala pengukuran menggunakan skala likert. Analisis yang digunakan analisis deskriptif dan regresi sederhana yang dimoderasi. 
Tabel 1. Kisi-Kisi Kuesioner

\begin{tabular}{|c|c|c|c|}
\hline $\begin{array}{l}\text { Variabel } \\
\text { Penelitian }\end{array}$ & Faktor & Indikator & $\begin{array}{l}\text { No. } \\
\text { Item }\end{array}$ \\
\hline \multirow{5}{*}{$\begin{array}{c}\text { Gaya } \\
\text { Kepemimpi- } \\
\text { nan }\end{array}$} & \multirow{5}{*}{$\begin{array}{l}\text { Individu } \\
\text { Pemimpin }\end{array}$} & Sifat & 8 \\
\hline & & Kebiasaan & 9,26 \\
\hline & & Watak & 11,27 \\
\hline & & Temperamen & 10 \\
\hline & & Kepribadian & 3,4 \\
\hline \multirow{14}{*}{ Budaya K3 } & \multirow{3}{*}{$\begin{array}{l}\text { Komitmen top } \\
\text { management }\end{array}$} & Ada pengawasan terhadap K3 para pekerja & 21 \\
\hline & & Perusahaan memberikan perlengkapan K3 & 22 \\
\hline & & Perusahaan memberikan pelatihan K3 & 23 \\
\hline & \multirow{2}{*}{$\begin{array}{c}\text { Peraturan dan } \\
\text { prosedur K3 }\end{array}$} & Ada sanksi terhadap pelanggaran prosedur K3 & 25 \\
\hline & & Peraturan dan prosedur $\mathrm{K} 3$ mudah dimengerti & 13,24 \\
\hline & \multirow{3}{*}{ Komunikasi } & Pekerja mendapat informasi mengenai masalahK3 & 18 \\
\hline & & $\begin{array}{l}\text { Adanya komunikasi yang baik antara pekerja dan } \\
\text { pihak manajerial }\end{array}$ & 12 \\
\hline & & $\begin{array}{l}\text { Adanya komunikasi yang baik antara sesama } \\
\text { pekerja }\end{array}$ & 5,14 \\
\hline & \multirow{2}{*}{$\begin{array}{l}\text { Kompetensi } \\
\text { pekerja }\end{array}$} & Pekerja mengerti tanggung jawab terhadap K3 & 6,7 \\
\hline & & $\begin{array}{l}\text { Pekerja mampu memenuhi seluruh peraturan dan } \\
\text { prosedur K3 }\end{array}$ & 1,2 \\
\hline & \multirow{2}{*}{$\begin{array}{l}\text { Keterlibatan } \\
\text { pekerja }\end{array}$} & $\begin{array}{l}\text { Pekerja puas dengan keamanan lingkungan kerja } \\
\text { (alat pengaman, kebersihan, pencahayaan) }\end{array}$ & 19 \\
\hline & & $\begin{array}{l}\text { Pekerja tidak saling menyalahkan bila terjadi } \\
\text { kecelakaan }\end{array}$ & 16,17 \\
\hline & \multirow[b]{2}{*}{ Lingkungan kerja } & Pekerja dilibatkan dalam perencanaan programK3 & 20 \\
\hline & & $\begin{array}{l}\text { Pekerja melaporkan jika terjadi kecelakaan atau } \\
\text { situasi yang bahaya }\end{array}$ & 15 \\
\hline
\end{tabular}

Sumber : Kartini K,2008; Christina, 2011; Notoatmojo, 2003; Asri, 1986.

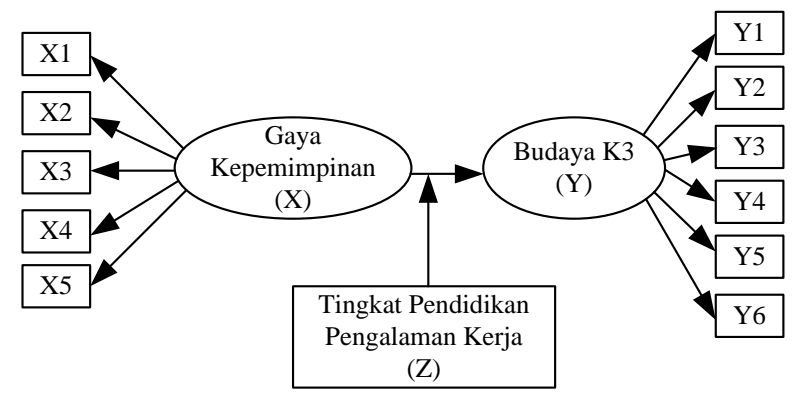

Gambar 1. Kerangka Penelitian

$\frac{\text { Tabel 2. Lokasi Proyek }}{\text { Nama Perusahaan }}$

\begin{tabular}{ll}
\hline \multicolumn{1}{c}{ Nama Perusahaan } & \multicolumn{1}{c}{ Nama Proyek } \\
\hline $\begin{array}{l}\text { PT.Surya Bangun } \\
\text { Persada Indah }\end{array}$ & $\begin{array}{l}\text { My Tower Hotel and } \\
\text { Apartement Surabaya }\end{array}$ \\
\hline $\begin{array}{l}\text { PT.Surya Bangun } \\
\text { Persada Indah }\end{array}$ & Swiss Bell Hotel \\
\hline $\begin{array}{l}\text { PT.Sinar Waringin } \\
\text { Adikarya }\end{array}$ & $\begin{array}{l}\text { Hotel Howard Johnson } \\
\text { Surabaya }\end{array}$ \\
\hline PT. Wijaya Kusuma & UC Town CitraLand \\
Construction & Surabaya \\
\hline PT. Wijaya Kusuma & KOZKO CitraLand \\
Construction & Surabaya \\
\hline PT. Pamenang Buana & Pembangunan Rumah \\
Raya & Dinas dan Gudang \\
\hline Sumer: Hasil Olahan & PT.Gudang Garam Tbk. \\
\hline
\end{tabular}

Sumer: Hasil Olahan
Hipotesis dalam penelitian dengan $\alpha=5 \%$ ini adalah sebagai berikut:

H1 : Gaya kepemimpinan berpengaruh signifikan terhadap budaya $\mathrm{K} 3$.

$\mathrm{H} 2$ : Tingkat pendidikan memoderasi pengaruh gaya kepemimpinan terhadap budaya K3 secar signifikan.

H3 : Pengalaman kerja memoderasi pengaruh gaya kepemimpinan terhadap budaya K3 secar signifikan.

$\mathrm{H} 2$ : Tingkat pendidikan dan pengalaman kerja memoderasi pengaruh gaya kepemimpinan terhadap budaya K3 secara signifikan

\section{HASIL DAN PEMBAHASAN \\ Gambaran Umum Responden}

Jenjang jabatan responden adalah Mandor (52\%), Pelaksana (18\%), Pengawas (12\%), Project Manager (10\%), dan Site Manager (8\%). Hal ini didominasi oleh jabatan sebagai mandor. Berdasarkan tingkat pendidikan responden adalah Perguruan Tinggi (52\%), SMU/STM (33\%), SMP/MTs (8\%), dan SD/MI (7\%). Jenjang pendidikan didominasi perguruan tinggi dan semuanya pernah menempuh pendidikan formal. Sedangkan berdasarkan pengalaman kerja $<3$ tahun (10\%), 3-4 tahun (10\%), 5-10 tahun (38\%). Dan >10 tahun (42\%), pengalaman kerja responden hampir $80 \%$ lebih dari 5 tahun. Gambaran umum ini sangat penting dalam mendesain kuesioner yang sesuai dengan tujuan penelitian. 
Tabel 3. Penilaian Gaya Kepempinan

\begin{tabular}{|c|c|c|c|c|c|c|c|}
\hline \multirow{2}{*}{ Indikator } & \multicolumn{5}{|c|}{ Skor Jawaban } & \multirow{2}{*}{ Rerata } & \multirow{2}{*}{ Penilaian } \\
\hline & 1 & 2 & 3 & 4 & 5 & & \\
\hline $\mathrm{X} 1$ & 1 & 5 & 15 & 29 & 10 & 3.7 & Baik \\
\hline $\mathrm{X} 2$ & 3 & 3 & 32 & 62 & 20 & 3.775 & Baik \\
\hline $\mathrm{X} 3$ & 3 & 7 & 24 & 66 & 20 & 3.775 & Baik \\
\hline $\mathrm{X} 4$ & 4 & 5 & 10 & 33 & 8 & 3.6 & Baik \\
\hline $\mathrm{X} 5$ & 1 & 6 & 34 & 55 & 24 & 3.792 & Baik \\
\hline \multicolumn{6}{|c|}{ Rerata } & 3.729 & Baik \\
\hline
\end{tabular}

Sumber : Data Primer

Tabel 4. Penilaian Budaya K3

\begin{tabular}{|c|c|c|c|c|c|c|c|}
\hline \multirow{2}{*}{$\begin{array}{c}\text { Indikato } \\
\mathrm{r}\end{array}$} & \multicolumn{5}{|c|}{ Skor Jawaban } & \multirow{2}{*}{$\begin{array}{c}\text { Rerat } \\
\text { a }\end{array}$} & \multirow{2}{*}{$\begin{array}{c}\text { Penilaia } \\
\mathrm{n}\end{array}$} \\
\hline & 1 & 2 & 3 & 4 & 5 & & \\
\hline Y1 & 2 & $\begin{array}{l}1 \\
2\end{array}$ & $\begin{array}{l}6 \\
6\end{array}$ & 75 & $\begin{array}{l}2 \\
5\end{array}$ & 3.606 & Baik \\
\hline $\mathrm{Y} 2$ & 7 & $\begin{array}{l}1 \\
3\end{array}$ & $\begin{array}{l}5 \\
5\end{array}$ & 75 & $\begin{array}{l}3 \\
0\end{array}$ & 3.596 & Baik \\
\hline $\mathrm{Y} 3$ & 1 & 7 & $\begin{array}{l}6 \\
7\end{array}$ & $\begin{array}{c}10 \\
7\end{array}$ & $\begin{array}{l}5 \\
8\end{array}$ & 3.892 & Baik \\
\hline Y4 & 1 & 0 & $\begin{array}{l}6 \\
0 \\
\end{array}$ & $\begin{array}{c}12 \\
1 \\
\end{array}$ & $\begin{array}{l}5 \\
8 \\
\end{array}$ & 3.979 & Baik \\
\hline Y5 & 2 & 6 & $\begin{array}{l}5 \\
2\end{array}$ & 94 & $\begin{array}{l}2 \\
6\end{array}$ & 3.708 & Baik \\
\hline Y6 & 2 & 4 & $\begin{array}{l}3 \\
4\end{array}$ & 58 & $\begin{array}{l}2 \\
2\end{array}$ & 3.783 & Baik \\
\hline & & Rer: & & & & 3.761 & Baik \\
\hline
\end{tabular}

Sumber : Data Primer

Pada tabel 3 penilaian responden terhadap gaya kepemimpinan dalam kategori baik, berarti gaya kepemimpinan memberikan dampak terhadap perilaku keselamatan pekerja dalam melaksanakan pekerjaannya. Pada tabel 4 penilaian respon terhadap budaya K3 dalam kategori baik, yang berarti budaya K3 dipelaksanaan proyek konstruksi berjalan dengan baik. Pada tabel 5 pertanyaan pada kuesioner adalah valid karena Corrected Item-Total Corelation lebih besar dari nilai 0,441 ( $\mathrm{r}$ tabel ), hal ini item pertanyaan di kuesioner mengukur sesuai dengan variabelnya. Sedangkan pada tabel 6 nilai Cronbach alpha lebih besar dari 0,7 ( Ghozali, 2016), hal ini menunjukkan bahwa item pertanyaan di kuesioner mempunya kekonsistenan dalam mengukur.

Tabel 5 Uji Validitas Variabel Gaya

Kepemimpinan dan Budaya K3

\begin{tabular}{|c|c|c|c|}
\hline Variabel & $\begin{array}{c}\text { Corrected } \\
\text { Item - Total } \\
\text { Correlation. }\end{array}$ & r Tabel & Keterangan \\
\hline \multicolumn{4}{|c|}{ Gaya Kepemimpinan (X) } \\
\hline $\mathrm{X} 1$ & 0.63 & 0,441 & Valid \\
\hline $\mathrm{X} 2$ & 0.548 & 0,441 & Valid \\
\hline $\mathrm{X} 3$ & 0.508 & 0,441 & Valid \\
\hline $\mathrm{X} 4$ & 0.749 & 0,441 & Valid \\
\hline $\mathrm{X} 5$ & 0.461 & 0,441 & Valid \\
\hline \multicolumn{4}{|c|}{ Budaya K3 (Y) } \\
\hline Y1 & 0.869 & 0,441 & Valid \\
\hline $\mathrm{Y} 2$ & 0.777 & 0,441 & Valid \\
\hline Y3 & 0.849 & 0,441 & Valid \\
\hline Y4 & 0.512 & 0,441 & Valid \\
\hline Y5 & 0.734 & 0,441 & Valid \\
\hline
\end{tabular}

\begin{tabular}{|c|r|r|r|}
\hline Y6 & 0.784 & 0,441 & Valid \\
\hline
\end{tabular}

Sumber : Data Primer

Tabel 6. Uji Reliabilitas Variabel Gaya Kepemimpinan dan Budaya K3

\begin{tabular}{|l|c|c|}
\hline Variabel & $\begin{array}{c}\text { Cronbach } \\
\text { Alpha }\end{array}$ & Keterangan \\
\hline $\begin{array}{l}\text { Gaya } \\
\text { Kepemimpinan } \\
(\mathrm{X})\end{array}$ & 0,786 & Valid \\
\hline Budaya K3 (Y) & 0,902 & Valid \\
\hline
\end{tabular}

Sumber ; Data Primer

\section{Uji Normalitas}

Uji normalitas tujuannya adalah apakah residualnya dari item pertanyaan dalam kuesioner berdistribusi normal atau tidak, untuk menguji normalitas digunakan metode Kolmogorov Smirnov. Nilai signifikannya 0,707, yang berarti lebih besar dari 0,05, hal ini berarti residual item pertanyaan berdistribusi normal.

\section{Uji Linearitas}

Uji lineritas bertujuan apakah variabel gaya kepemimpinan dengan budaya K3 mempunyai asumsi linearitas (Suliyanto, 2011). Metode yang digunakan adalah uji Fisher. Kedua variabel tersebut dikatakan linier bila nilai signifikandari Deviation from Linearity lebih besar dari nilai alpha 0,05 , karena nilai signifikansinya 0,127 maka kedua variabel memenuhi asumsi linearitas.

\section{Hubungan Gaya Kepemimpinan Dengan Budaya K3}

Besarnya korelasi Gaya Kepemimpinan dengan Buadaya K3 dengan metode korelasi product moment yaitu $\mathrm{R}=0,674$ dan signifikan $(\alpha<5 \%)$, berarti kedua variabel tersebut mempunyai hubungan yang kuat (Sugiyono, 2008). Hubungan kedua variabel sesuai dengan penelitian Gunawan (2013); Gunawan \& Waluyo (2015); Faris I \& Feri H. (2014) yang menyatakan peranan kepemimpinan sangat penting dalam membangun budaya $\mathrm{K} 3$.

\section{Pengaruh Gaya Kepemimpinan terhadap Budaya K3}

Berdasarkan hasil analisis regresi linear sederhana maka pada diperoleh koefisien regresi gaya kepemimpinan sebesar 0,516 , dengan nilai t hitung 6,947 lebih besar dari $\mathrm{t}$ tabel df $(0,05 ; 58)$ sebesar $(1,672)$, sedangkan nilai sig. sebesar 0,000 . Karena $t$ hitung $(6,947)>\mathrm{t}$ tabel $(1,672)$ atau nilai sig. $(0,000)<$ alpha $(0,05)$, maka variabel gaya kepemimpinan berpengaruh positif terhadap budaya K3. Dengan demikian hipotesis H1 diterima, yang menyatakan bahwa Gaya Kepemimpinan berpengaruh positif dan signifikan terhadap budaya keselamatan dan kesehatan kerja. Hal ini sejalan dengan penelitian Papang A \& Feri H (2014); Gunawan (2013); Faris I \& Feri H. (2014); Gunawan \& Waluyo (2015).

\section{Pengaruh Gaya Kepemimpinan terhadap Budaya K3 yang dimoderasi Tingkat Pendidikan}

Hasil Analisis regresi linear sederhana yang yang dimoderasi diperoleh koefisien nilai mutlak residual 
regresi variabel gaya kepemimpinan dengan variabel moderasi tingkat pendidikan sebesar $-0,337$ dengan nilai t hitung sebesar $-3,362$ dengan $t$ tabel df $(0,05 ; 58)$ sebesar $(1,672)$, sedangkan nilai sig. sebesar 0,001 , karena $t$ hitung < t tabel atau nilai sig. < alpha $(0,05)$, maka variabel tingkat pendidikan berpengaruh negatif terhadap nilai absolute residual. Sehingga dapat disimpulkan tingkat pendidikan memoderasi dan memperlemah hubungan antara gaya kepemimpinan dengan budaya $\mathrm{K} 3$. Dengan demikian hipotesis $\mathrm{H} 2$ diterima, yang menyatakan bahwa Tingkat Pendidikan memoderasi pengaruh Gaya Kepemimpinan terhadap Budaya K3. Hal ini sejalan dengan Gunawan (2013); Suhardjo(2006) ; Notoatmodjo (2003); Gunawan \& Waluyo (2015).

\section{Pengaruh Gaya Kepemimpinan terhadap Budaya K3 yang dimoderasi Pengalaman Kerja}

Hasil Analisis regresi linear sederhana yang yang dimoderasi diperoleh koefisien nilai mutlak residual regresi variabel gaya kepemimpinan dengan variabel moderasi tingkat pendidikan sebesar 0,015 dengan nilai $t$ hitung sebesar 0,104 dengan $\mathrm{t}$ tabel df $(0,05 ; 58)$ sebesar $(1,672)$, sedangkan nilai sig. sebesar 0,917 , karena $t$ hitung $<\mathrm{t}$ tabel atau nilai sig. $>$ alpha $(0,05)$, maka variabel pengalaman kerja tidak berpengaruh terhadap nilai absolute residual. Dengan demikian hipotesis $\mathrm{H} 3$ ditolak, yang menyatakan bahwa Pengalaman Kerja tidak memoderasi pengaruh Gaya Kepemimpinan terhadap Budaya K3. Oleh karena itu pengalaman kerja bukan merupakan variabel moderator, melainkan variabel bebas. Variabel yang dihipotesiskan gagal menjadi variabel moderator namun menjadi variabel bebas. Hal ini tidak sejalan dengan Gunawan (2013); Handoko (1987); Gunawan \& Waluyo (2015).

\section{Pengaruh Gaya Kepemimpinan terhadap Budaya K3 yang dimoderasi Tingkat Pendidikan dan Pengalaman Kerja}

Hasil analisis diperoleh koefisien nilai mutlak residual regresi variabel gaya kepemimpinan dengan interaksi variabel moderasi tingkat pendidikan dan pengalamankerja sebesar -1,321 dengan nilai $t$ hitung sebesar -1,907 dengan $\mathrm{t}$ tabel df $(0,05 ; 58)$ sebesar ($1,672)$, sedangkan nilai sig. sebesar 0,061 , karena t hitung $>\mathrm{t}$ tabel atau nilai sig. > alpha $(0,05)$, maka variabel pengalaman kerja tidak berpengaruh terhadap nilai absolute residual. Hal ini berarti kedua variabel moderator tersebut secara bersama pada nilai mutlak residual tidak berpengaruh terhadap hubungan antara gaya kepemimpinan dengan budaya K3. Dengan demikian hipotesis H4 ditolak, yang menyatakan bahwa Tingkat Pendidikan dan Pengalaman Kerja (secara bersama) tidak memoderasi pengaruh Gaya Kepemimpinan terhadap Budaya K3.

Dengan demikian tingkat pendidikan tinggi tidak menjamin seseorang untuk merubah budaya hidupnya terlebih lagi saat bekerja dengan resiko kecelakaan yang tinggi. Kurangnya pemahaman, pengetahuan akan kesehatan lingkungan, perilaku hidup sehat dan resiko kecelakaan pada pekekerjannya sebagai salah satu faktor melemahnya pengaruh tingkat pendidikan pada hubungan antara gaya kepemimpinan dengan budaya K3. Hal ini juga menjadi penyebab tidak berpengaruhnya variabel pengalaman kerja terhadap hubungan antara gaya kepemimpinan dengan budaya K3. Karena berdasarkan pengalaman kerja justru para tim menyepelekan resiko kecelakaan kerja yang tidak pernah diduga.

\section{UCAPAN TERIMA KASIH}

Terima kasih atas kerjasamanya dalam penelitian kepada pihak manajemen PT. Surya Bangun Persada, PT. Sinar Waringin Adikarya, PT. Wijaya Kusuma Construction, dan PT. Pemenang Buana Karya.

\section{KESIMPULAN DAN SARAN}

Berdasarkan dari hasil analisis tersebut maka kesimpulan dari penelitian ini adalah :

- Gaya kepemimpinan berpengaruh secara signifikan terhadap budaya K3 (sig.0,000<0,05)

- Tingkat pendidikan mempengaruhi secara signifikan terhadap budaya K3 (Sig 0,001 <0,05). Tetapi memperlemah hubungan antara gaya kepemimpinan terhadap budaya K3.

- Pengalaman kerja tidak berfungsi sebagai variabel moderator (Sig 0,917>0,05). Tetapi berfungsi sebagai variabel bebas.

- Hasil interaksi tingkat pendidikan dan pengalaman kerja tidak mempengaruhi signifikan hubungan antara gaya kepemimpinan terhadap budaya K3 (Sig $0,061>0,05)$.

Adapun beberapa saran untuk penelitian ini yaitu :

- Bagi instansi, faktor tingkat pendidikan dan pengalaman kerja bukanlah salah satu faktor yang mempengaruhi budaya $\mathrm{K} 3$, tetapi hanyalah sebagian dari pengaruh budaya K3. Oleh sebab itu, dibutuhkan pelatihan tentang pengetahuan risiko kecelakaan kerja kepada semua karyawan yang berhubungan dengan pelaksanaan proyek kontruksi.

- Untuk penelitian selanjutnya perlu ditambahkan variabel lain yang mempengarugi budaya K3.

\section{DAFTAR PUSTAKA}

Asri, Marwa. (1986). Pengelolahan Karyawan. Yogyakarta ; BPFE.

Aprillia, Karlina \& Ghozali , Imam. (2013). Teknik Penyusunan Skala Likert. Semarang : Fakultas ekonomi dan Bisnis, Iniversitas Diponegoro.

Christina, Wieke Yuni, dkk. (2012). Pengaruh Budaya Keselamatan dan Kesehatan Kerja (K3) Terhadap Kinerja Proyek Konstruksi. Jurnal Rekayasa Sipil; Fakultas Teknik Sipil, Universitas Brawijaya Malang; Vol. 6, No.1.

F.A. Gunawan \& Waluyo.(2015). Risk Based Behavioral Safety. Jakarta; PT. Gramedia Pustaka Utama.

F.A. Gunawan. (2013). Safety Leadership. Jakarta: Dian Rakyat.

Faris Iqbal Al. \& Feri Harianto..(2013). Pengaruh Perilaku Tenaga Kerja Dan Lingkungan Kerja Yang 
Dimoderasi Faktor Pengalaman Kerja dan Tingkat Pendidikan Terhadap Kecelakaan Kerja Konstruksi Di Surabaya. Jurnal Ilmiah Teknik Sipil, Fakultas Teknik Sipil Institut Teknologi Adhi Tama Surabaya.

Handoko, Hani. ( 1987). Manajemen Personaliadan Sumber Daya Manusia. Edisi Kedua. Yogyakarta : BPFE.

Kartono, Kartini. (2008). Pemimpin Dan Kepemimpinan: Apakah Kepemimpinan Abnormal Itu?. Ed. 1, Cet, 18, Jakarta: Rajawali Press.

Muhammad.D.I, dkk. (2017). Worker's Age and The Impact of Psikological Factors on The Perception of Safety at Construction Site. Journal Sustainability.www.mdpi.com.
Notoatmodjo, S. (2003). Pengantar PendidikanKesehatan dan Ilmu Perilaku.Yogyakarta: Andi offset.

Robbins, Stephen P. \& Jugde, Timothy A.(2009). Organizational Behaviour (13th). New Jersey : Prentice-Hall, Inc.

Sugiyono. (2008). Metode penelitian Kuantitatif, kualitataif dan $R \& D$. Bandung: Alfabeta.

Suliyanto, (2011). Ekonometrika Terapan. Yogyakarta: Andi offset.

Suhardjo. (2006). Mengenal Pendidikan Sekolah Dasar. Jakarta : Departemen Pendidikan Nasional.

Solimun dkk. (2018). Metodologi Penelitian Kuantitatif Perspektif Sistem. Malang: UB Press.

Suma'mur. (1996). Keselamatan Kerja dan Pencegahan Kecelakaan. Jakarta: Penerbit Haji Masagung. 
Jurnal Rekayasa Tenik Sipil Universitas Madura Vol. 4 No.2 Desember 2019 ISSN 2527-5542

Halaman Sengaja Dikosongkan 


\title{
Studi Eksperimental Penambahan Serbuk Arang Kayu Dengan Kadar 10\% Terhadap Filler Semen Pada Campuran Perkerasan AC - WC
}

\author{
Kurnia Hadi Putra ${ }^{1}$, Mutiara Fidausi ${ }^{2}$ \\ Jurusan Teknik Sipil - FTSP - ITATS ${ }^{1}$, Jurusan Teknik Sipil - FTSP - ITATS ${ }^{2}$ \\ Email: kurnia_putra@itats.ac.id
}

\begin{abstract}
ABSTRAK: Jenis lapis perkerasan aspal yang sifatnya struktural dan umum dipakai di Indonesia adalah Lapis Aspal Beton (Laston) dengan lapis aus atau lapis permukaan (Wearing Course). Lapisan tersebut merupakan lapisan yang paling rentan dengan kerusakan yang diakibatkan oleh repitisi beban kendaraan dan cuaca. Penelitian ini mecoba serbuk arang kayu dapat dimanfaatkan sebagai filler dalam campuran aspal sebagai alternatif pengganti semen. Dalam penelitian ini pembuatan benda uji mengacu pada Spesifikasi Bina Marga 2010 (Divisi VI). Digunakan variasi serbuk arang kayu 10\%. Dari data Marshall Test yang didapatkan, memenuhi persyaratan sesuai Spesifikasi Bina Marga 2010 adalah serbuk arang kayu yang berkadar 10\%. Pada benda uji serbuk arang kayu 10\% dihasilkan VIM sebesar 5,32 \%, VMA sebesar 17,81, Void Filled sebesar 70,18, stabilitas sebesar 1354, Flow sebesar 3,17, Marshall Quetiont sebesar 427,5 , tebal selimut aspal sebesar 8,020. Sehingga dapat di simpulkan bahwa kandungan variasi serbuk arang kayu $10 \%$ meningkatkan nilai Marshall Test.
\end{abstract}

Kata Kunci : Filler, Serbuk arang kayu, Lapisan aspal beton AC-WC, Uji Marshall.

\section{LATAR BELAKANG}

Jalan raya merupakan salah satu prasarana perhubungan darat yang mempunyai peranan penting bagi pertumbuhan perekonomian, sosial budaya, pengembangan wilayah pariwisata, dan pertahanan keamanan untuk menunjang pembangunan nasional. [1]

Perkembangan masyarakat telah berdampak kepada semakin banyaknya permintaan akan jasa transportasi jalan raya. Tingginya permintaan terhadap jasa transportasi jalan raya tidak hanya ditandai dengan meningkatnya volume lalu lintas kendaraan tetapi juga dengan tekanan beban kendaraan yang tinggi sehingga struktur lapis perkerasan jalan beraspal dituntut untuk dapat melayani dengan baik perubahan-perubahan tersebut. Sementara di sisi lain faktor cuaca dan suhu juga sangat mempengaruhi keawetan lapis permukaan aspal. [2]

Semakin banyaknya tingkat kecelakaan lalu lintas di Indonesia. Kecelakaan lalu lintas merupakan masalah yang membutuhkan penanganan serius mengingat besarnya kerugian yang diakibatkannya. Salah satu faktor dalam kecelakaan di jalan raya adalah kerusakan suatu jalan tersebut. Adapun salah satu contohnya yaitu genangan air di permukaan pekerasan jalan. Tergenangnya air di permukaan jalan raya yang disebabkan oleh air hujan dapat membahayakan pengguna jalan raya, sehingga keselamatan mereka terancam kejadian kecelakaan. Maka dari itu, untuk menjaga keselamatan para pengguna jalan perlu perencanaan struktur perkerasan jalan yang baik. [2]

Salah satu jenis Lapis perkerasan aspal yang sifatnya struktural dan umum dipakai di Indonesia adalah Lapis Aspal Beton (Laston) dengan lapis aus atau lapis permukaan (Wearing Course). Lapisan tersebut merupakan lapisan yang paling rentan dengan kerusakan yang diakibatkan oleh repitisi beban kendaraan dan cuaca. Telah banyak dilakukan berbagai penelitian tentang pencampuran bahan aditif (bahan tambah) dengan campuran perkerasan Laston-WC yang bertujuan meningkatkan stabilitas aspal. Berdasarkan hal tersebut, dilakukan penelitian penambahan serbuk arang kayu ke dalam aspal yang bertujuan meningkatkan titik lembek aspal, memperkecil nilai penetrasi aspal dan memperkecil presentase kehilangan berat aspal akibat pemanasan. [3]

Salah satu jenis Lapis perkerasan aspal yang sifatnya struktural dan umum dipakai di Indonesia adalah Lapis Aspal Beton (Laston) dengan lapis aus atau lapis permukaan (Wearing Course). Lapisan tersebut merupakan lapisan yang paling rentan dengan kerusakan yang diakibatkan oleh repitisi beban kendaraan dan cuaca. Telah banyak dilakukan berbagai penelitian tentang pencampuran bahan aditif (bahan tambah) dengan campuran perkerasan Laston-WC yang bertujuan meningkatkan stabilitas aspal. Berdasarkan hal tersebut, dilakukan penelitian penambahan serbuk arang kayu ke dalam aspal yang bertujuan meningkatkan titik lembek aspal, memperkecil nilai penetrasi aspal dan memperkecil presentase kehilangan berat aspal akibat pemanasan. [3]

Arang kayu (Wood Charcoal) adalah residu yang mengandung karbon yang dihasilkan dengan cara dibakar dengan pemanasan pada suhu tinggi dengan bahan dasar kayu. Arang berwarna hitam, berbobot ringan, $80 \%$ komposisinya berupa karbon. Arang ini terdiri 85\% sampai $98 \%$ karbon, sisanya adalah abu atau benda kimia lainnya. Melihat kondisi arang kayu yang mengandung karbon aktif tersebut, diharapkan pecampuran arang kayu kedalam aspal dapat meningkatkan kinerja dari pekerasan Laston-WC seperti nilai daktilitas, menahan penguapan ketika dipanaskan (menaikkan titik nyala) dan sifat-sifat dasar aspal lainnya. [4] 


\section{METODE PENELITIAN}

\section{Pengujian Aspal Pen 60/70}

Pemeriksaan sifat aspal pen 60/70 dari campuran perkerasan Laston-WC dilakukan melalui beberapa uji meliputi:

1. Uji penetrasi

2. Titik Lembek

3. Berat Jenis

4. Titik Nyala dan Titik Bakar

5. Kelekatan Aspal pada Agregat

\section{Uji penetrasi}

Percobaan ini bertujuan untuk mentukan apakah aspal keras atau lembek (solid atau semi solid) dengan memasukkan jarum penetrasi ukuran tertentu, beban, waktu tertentu kedalam aspal pada suhu tertentu. Pengujian ini dilakukan dengan membebani permukaan aspal seberat 100 gram pada tumpuan jarum berdiameter $1 \mathrm{~mm}$ selam 5 detik pada temperatur $25^{\circ} \mathrm{c}$.

\section{Titik Lembek}

Titik lembek adalah temperature pada saat bola baja dengan berat tertentu mendesak turun suatu lapisan aspal yang tertahan dalam cincin berukuran tertentu, sehingga aspal tersebut menyentuh plat dasar yang terletak di bawah cincin pada tinggi tertentu sebagai akibat kecepatan pemanasan tertentu.

\section{Daktalitas}

Pengujian daktalitas ini bertujuan untuk mengetahui sifat kohesi dari aspal, dengan mengukur jarak terpanjang yang dapat di tarik antara dua cetakan yang berisi aspal keras sebelum putus, pada suhu dan kecepatan tertentu.

\section{Berat Jenis}

Pengujian ini bertujuan untuk menentukan berat jenis aspal keras dengan alat piknometer. Berat jenis aspal adalah perbandingan antar berat aspal dan berat zat cair suling dengan volume yang sama pada suhu $25^{\circ} \mathrm{c}$.

\section{Pengujian Agregat}

Pemilihan agregat yang tepat dan memenuhi persyaratan akan sangat menetukan daya dukung perkerasan dan keberhasilan pembangunan atau pemeliharaan jalan. Pada campuran beraspal, agregat memberikan kontribusi sampai 90\%-95\% terhadap berat campuran, sehingga sifat-sifat agregat merupakan salah satu faktor penentu dari kinerja campuran tersebut.

1. Sifat agregat yang harus diperiksa antara lain:

2. Ukuran butir

3. Gradasi

4. Kebersihan

5. Kekerasan

6. Bentuk partikel

7. Tekstur permukaan

8. Penyerapan

9. Kelekatan terhadap aspal

Berat jenis suatu agregat adalah perbandingan berat dari suatu satuan volume bahan terhadap berat air dengan volume yang sama pada temperature $20^{\circ} \mathrm{C}-25^{\circ} \mathrm{C}\left(68^{\circ} \mathrm{F}\right.$ $77^{\circ} \mathrm{F}$ ). beberapa macam berat jenis agregat:
- Berat jenis semu (apparent specific gravity), Berat jenis semu, volume dipandang sebagi volume pori yang dapat terisi air setelah perendaman selam 24 jam.

- Berat jenis bulk (bulk specific gravity), Berat jenis bulk, volume dipandang volume menyeluruh agregat termasuk volume pori yang dapat terisi oleh air setelah direndam selama 24 jam.

- Berat jenis efektif, Berat jenis efektif, volume dipandang volume menyeluruh dari agregat tidak termasuk volume pori yang dapat menghisap aspal.

\section{Pengujian Marshall}

Pada percobaan ini menggunakan benda uji standar berupa sebuah cetakan yang berdiameter 101,6 mm (4 inci) dan tinggi $75 \mathrm{~mm}$ (3 inci). Benda uji didapatkan dengan menggunakan alat pemadat Marshall (Marshall Compaction Hummer) dengan berat 4,54 kg (10 lbs), diameter 3. 7/8 inci dan tinggi jatuh $457 \mathrm{~mm}$ (18 inci). Hasil uji akan menunjukkan karakteristik Marshall dan karakteristik akan dipengaruhi oleh sifat-sifat campuran yaitu: Kepadatan, Rongga mineral diantara Agergat (VMA), Rongga terisi aspal (VFA), Rongga udara dalam campuran (VIM), Nilai stabilitas dan Pelelehan.

\section{HASIL PENELITIAN Pengujian Aspal}

Dalam penelitian ini, aspal yang digunakan adalah aspal Pertamina dengan penetrasi 60/70.

Tabel 1. Hasil Pengujian Sifat Fisik Aspal Penetrasi $60 / 70$

\begin{tabular}{|c|c|c|c|c|c|c|}
\hline \multirow[t]{2}{*}{ No } & \multirow{2}{*}{$\begin{array}{c}\text { Jenis } \\
\text { Pemeriksaa } \\
\mathrm{n}\end{array}$} & \multirow[t]{2}{*}{ Unit } & \multirow[t]{2}{*}{ Metode Uji } & \multicolumn{2}{|c|}{ Spesifikasi } & \multirow{2}{*}{$\begin{array}{c}\text { Hasil } \\
\text { pemeriks } \\
\text { aan }\end{array}$} \\
\hline & & & & Min & $\operatorname{Max}$ & \\
\hline 1 & $\begin{array}{l}\text { Penetrasi } \\
25^{\circ} \mathrm{c}, 100 \mathrm{gr} \text {, } \\
5 \text { detik }\end{array}$ & $\mathrm{mm}$ & $\begin{array}{l}\text { SNI 06- } \\
2456-1991\end{array}$ & 60 & 70 & 70 \\
\hline 2 & $\begin{array}{l}\text { Titik } \\
\text { Lembek } 5^{\circ} \mathrm{c}\end{array}$ & ${ }^{\circ} \mathrm{C}$ & $\begin{array}{l}\text { SNI 2434- } \\
2011\end{array}$ & 48 & - & 49 \\
\hline 3 & Titik Nyala & ${ }^{\circ} \mathrm{C}$ & $\begin{array}{l}\text { SNI 2433- } \\
2011\end{array}$ & 232 & - & 312 \\
\hline 4 & $\begin{array}{l}\text { Kehilangan } \\
\text { Berat } \\
\text { (dengan } \\
\text { TFOT) }\end{array}$ & $\%$ & $\begin{array}{l}\text { SNI 06- } \\
\text { 2441-1991 }\end{array}$ & - & 0,8 & 0.2073 \\
\hline 5 & $\begin{array}{l}\text { Kelarutan } \\
\text { aspal dalam } \\
\text { C2HCL3 }\end{array}$ & $\%$ & $\begin{array}{l}\text { AASHTO } \\
\text { T44-03 }\end{array}$ & 99 & - & 99.713 \\
\hline 6 & Berat jenis & $\begin{array}{l}\mathrm{gr} / \mathrm{c} \\
\mathrm{c}\end{array}$ & $\begin{array}{l}\text { SNI 2441- } \\
2011\end{array}$ & 1 & - & 1.032 \\
\hline
\end{tabular}

\section{Pemeriksaan Penetrasi Aspal}

Pengujian ini didasarkan pada SNI 06-2456-1991. Dari hasil pengujian, didapatkan nilai penetrasi 70 yang menunjukkan termasuk aspal penetrasi 60/70. Nilai penetrasi ini memenuhi Spesifikasi Departemen 
Pekerjaan Umum tahun 2010 Revisi III yaitu nilai penetrasi aspal pada rentang 60-70.

\section{Pemeriksaan Titik Lembek}

Pengujian ini didasarkan pada SNI 2434-2011. Nilai yang didapatkan dari hasil pemeriksaan titik lembek aspal sebesar $49^{\circ} \mathrm{c}$. Nilai ini telah memenuhi Spesifikasi Departemen Pekerjaan Umum Tahun 2010 Revisi III yang telah menetapkan persyaratan titik lembek minimal $48^{\circ} \mathrm{c}$.

\section{Pemeriksaan Titik Nyala}

Pengujian ini didasarkan pada SNI 2433-2011. Dari hasil pemeriksaan aspal penetrasi 60/70 titik bakarnya adalah sebesar $312^{\circ} \mathrm{c}$ dan nilai titik nyal yaitu $232^{\circ} \mathrm{c}$ ini telah memenuhi dalam Spesifikasi Departemen Pekerjaan Umum Tahun 2010 Revisi III.

\section{Pemeriksaan Kehilangan Berat}

Pengujian ini didasarkan pada SNI 06-2441-1991. Pada pemeriksaan ini kehilangan berat ini menggunakan sampel yang sama untuk penetrasi, yaitu setelah aspal dilakukan TFOT. Hasil pemeriksaan kehilangan berat ini menunjukkan aspal kehilangan berat sebesar 0,2073. Hasil ini sama seperti Spesifikasi Departemen Pekerjaan Umum Tahun 2010 Revisi III yang menetapkan persyaratan maksimal sebesar $0,4 \%$.

\section{Pemeriksaan Kelarutan Aspal Dalam Karbon} Tetraklorida (C2HCL3)

Di dalam pengujian ini didasarkan pada SNI 06-24381991. Nilai pemeriksaan kelarutan menujukkan kemurnian aspal dan normalnya bebas dari air. Pengujian ini ini didasarkan pada nilai kelarutan C2HCL3 adalah sebesar $99.713 \%$, yang masih memenuhi Spesifikasi Departemen Pekerjaan Umum Tahun 2010 Revisi III yang menetapkan persyaratan minimalnya sebesar $99 \%$.

\section{Pemeriksaan Berat Jenis Aspal}

Didalam pengujian ini didasarkan pada SNI 2441-2011. Dari hasil pengujian ini didapatkan berat jenis aspla sebesar $1.0228 \mathrm{gr} / \mathrm{cc}$, dimana hasil ini telah memenuhi Spesifikasi Departemen Pekerjaan Umum Tahun 2010 Revisi III yang menetapkan batas minimum berat jenis aspal sebesar $1 \mathrm{gr} / \mathrm{cc}$.

\section{Pengujian Agregat}

Untuk mengetahui sifat-sifat atau karakteristik agregat, pada penelitian ini pengujian agregat yang dilakukan dari Coarse Aggregate, Medium Aggregate, Fine Aggregate serta Stone Dust. Pengujian ini dilakukan didasarkan pada Standart Nasional Indonesia (SNI). Gradasi yang ditinjau didasarkan pada gradasi laston lapis permukaan (AC-WC) dari Spesifikasi Departemen PU Tahun 2010.

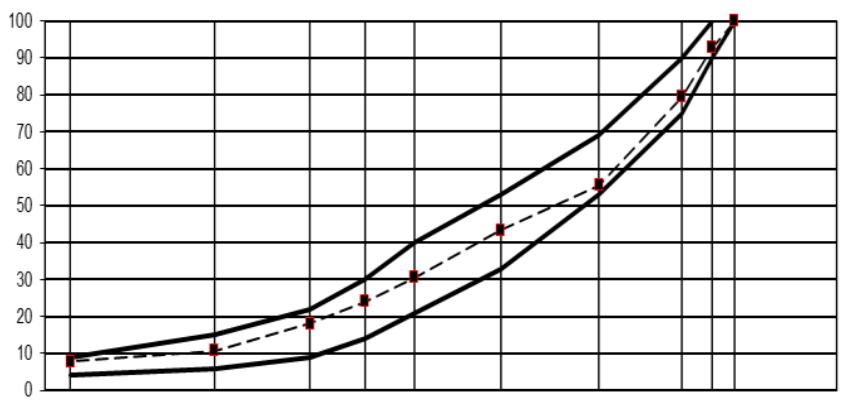

Gambar 1. Kombinasi Gradasi Agregat
Tabel 2. Pengujian Berat Jenis

\begin{tabular}{|c|l|c|c|c|c|}
\hline No. & Agregat & Berat Jenis & $\begin{array}{c}\text { Berat } \\
\text { Jenuh }\end{array}$ & $\begin{array}{l}\text { Berat } \\
\text { Kering }\end{array}$ & Penyerapan \\
\hline 1 & Agregat halus & 2.565 & 2.611 & 2.691 & 1.829 \\
\hline 2 & Agregat sedang & 2.575 & 2.625 & 2.711 & 1.943 \\
\hline 3 & Agregat Kasar & 2.694 & 0.915 & 2.823 & 1.002 \\
\hline 4 & Filler & 3.150 & & 3.150 & \\
\hline
\end{tabular}

\section{Komposisi Dan Proporsi Benda Uji Marshall}

Komposisi dan penentuan proporsi agregat dibuat dari data-data hasil analisis butiran masing-masing agregat yang tertahan di masing-masing saringan. Jenis campuran yang digunakan adalah gradasi kasar yang sesuai dengan peruntukan campuran AC-WC berdasarkan Spesifikasi Departemen Pekerjaan Umum tahun 2010. Pada penelitian ini, bahwa jumlah sampel yang dibutuhkan untuk mencari kadar aspal ideal sebanyak 9 buah dengan variasi kadar aspal 4\%, 5\%, 6\%. Sampel benda uji dibuat dengan metode Marshall.

\section{Komposisi Dan Proporsi Benda Uji Marshall}

Komposisi dan penentuan proporsi agregat dibuat dari data-data hasil analisis butiran masing-masing agregat yang tertahan di masing-masing saringan. Jenis campuran yang digunakan adalah gradasi kasar yang sesuai dengan peruntukan campuran AC-WC berdasarkan Spesifikasi Departemen Pekerjaan Umum tahun 2010. Pada penelitian ini, bahwa jumlah sampel yang dibutuhkan untuk mencari kadar aspal ideal sebanyak 9 buah dengan variasi kadar aspal 4\%, 5\%,6\%. Sampel benda uji dibuat dengan metode Marshall.

\section{KESIMPULAN}

Kesimpulan dalam penelitian ini, dapat dilihat pengaruh dalam penggunan variasi serbuk arang kayu $10 \%$ sebagai bahan tambah campuran perkerasan AC-WC adalah dengan penambahan kadar seruk arang kayu $10 \%$ terhadap filler semen dapat meningkatkan nilai Marshall Test. Dari data Marshall Test. Didapatkan data berdasarkan analisis kadar filler serbuk arang kayu sebesar 10\% diperoleh nilai stabilitas sebesar $1354 \mathrm{~kg}$, nilai flow sebesar 3,17 mm, Marshall Quetiont sebesar $427,50 \mathrm{~kg} / \mathrm{mm}$, VIM sebesar 4.34\%, VMA sebesar 17.81 $\%$, Void filled sebesar 70,18\%.

\section{DAFTAR PUSTAKA}

[1] Sukirman, Silvia;. (2010). Perencana Tebal Struktur Perkerasan Lentur. Bandung: Nova. 
[2] Permana, Shezy Nurhayati; Prasetyanto, Dwi; Zurni, Rahmi;. (n.d.). Studi Penggunaan Limbah Las Karbit Untuk Bahan Tambah Pada Perkerasan Laston $A C$ - $W C$.

[3] Hendarsin, L Shirley (2000), Perencanaan Teknik Jalan Raya. Politeknik Negeri Bandung

[4] Polii, Fahri Ferdinand; (2017). Pengaruh Suhu Dan Lama Aktifasi Terhadap Mutu Arang Aktif Dari Kayu Kelapa. Balai Riset Dan Standarisasi Manado.

[5] Badan Standarisasi Nasional, 1991, SNI 062433-1991, Cara Uji Titik Nyala Dan Titik Bakar Aspal Dengan Alat Cleveland Open Cup. Departemen Pekerjaan Umum, Badan Penelitian dan Pengembangan Departemen Pekerjaan Umum.

[6] Bina Marga Direktorat Jendaral, Spesifikasi Umum tahun 2010 Revisi III. Departemen Pekerjaan Umum. Jakarta

[7] Badan Standarisasi Nasional, 2008, SNI 2417:2008, Cara Uji Keausan Agregat Dengan Mesin Abrasi Los Angeles, Departemen Pekerjaan Umum, Badan Penelitian dan Pengembangan Departemen Pekerjaan Umum.

[8] Badan Standarisasi Nasional, 1991, SNI 062441-1991, Cara Uji Berat Jenis Aspal Keras, Departemen Pekerjaan Umum, Badan Penelitian dan Pengembangan Departemen Pekerjaan Umum.

[9] Badan Standarisasi Nasional, 1991, SNI 062456-1991, Cara Uji Penetrasi Aspal, Departemen Pekerjaan Umum, Badan Penelitian dan Pengembangan Departemen Pekerjaan Umum.

[10] RSNI M-01-2003;. Metode Pengujian Campuran Beraspal Panas Dengan Alat Marshall. Badan Standardisasi Nasional.

[11] Kementerian Pekerjaan Umum Dan Perumahan Rakyat;(2017). Manual Perkerasan Jalan. Jakarta: Direktorat Jenderal Bina Marga.

[12] Departemen Pekerjaan Umum: 2002. Pedoman Perkerasan Lentur Metode Bina Marga (Pt T-01-2002-B), Jakarta. 


\title{
Analisis Penerapan Sistem Manajemen K3 dan Kelengkapan Fasilitas K3 Pada Proyek Konstruksi Gedung Di Surabaya
}

\author{
Arizal Firmansyah Priyono ${ }^{1}$ dan Feri Harianto ${ }^{2}$ \\ ${ }^{1,2}$ Jurusan Teknik Sipil, Fakultas Teknik Sipil dan Perencanaan,ITATS, Surabaya \\ E-mail: arizal.firmans@gmail.com ${ }^{1}$,gokbio@yahoo.com ${ }^{2}$
}

\begin{abstract}
ABSTRAK:Proyek konstruksi gedung bertingkat memiliki risiko kecelakaan kerja yang tinggi, khususnya bagi pekerja di lapangan. Oleh karena itu, perlu adanya penerapan Sistem Manajemen K3 serta fasilitas K3 yang lengkap dan layak di lokasi kerja. Sistem Manajemen K3 merupakan bagian dari perencanaan dan pengendalian kecelakaan pada proyek konstruksi. Tujuan penelitian ini adalah menganalisis penerapan SMK3 dan kelengkapan fasilitas K3 serta membandingkan antara 3 proyek konstruksi gedung yang ada di Kota Surabaya. Metode penelitian yang digunakan adalah metode survai dengan pengambilan data dilakukan melalui kuesioner dengan respondennya adalah Manager, Safety Officer dan Quality Control. Analisis penerapan Sistem Mnajemen K3 berdasarkan audit Permenaker no.5 tahun 1996. Hasil dari penelitian ini untuk proyek Apartemen BeSS Mansion nilai rata-rata pencapaian adalah 92,56\% , proyek Gedung Ciputra World nilai rata-rata pencapaian 91,80\% , dan proyek Gedung C dan Masjid Kampus Perbanas II nilai rata-rata pencapaian $89,76 \%$. Kriteria ketiga proyek tersebut adalah memuaskan. Sedangkan hasil analisis kelengkapan APD dan fasilitas K3 pada proyek Apartemen BeSS Mansion mendapat nilai rata-rata 95,55\%, proyek Gedung Ciputra World dengan nilai rata-rata 93,67\%, dan pada proyek Gedung C dan Masjid Kampus Perbanas II mendapat nilai rata-rata 73,33\%. Adapun terdapat 4 faktor yang mempengaruhi perbedaan dalam penerapan SMK3 di ketiga proyek tersebut yaitu faktor perencanaan, faktor perusahaan kontraktor, faktor kesiapan manajemen, faktor kesadaran manajemen. Dengan demikian, untuk ketiga proyek tersebut telah siap Permenaker no.5 tahun 1996. Namun perlu adanya perbaikan atau perencanaan kembali pada kriteria-kriteria yang tidak sesuai, serta memperhatikan APD dan fasilitas proyek yang kurang layak dan tidak lengkap.
\end{abstract}

Kata Kunci : keselamatan, kesehatan, manajemen k3, fasilitas k3, perbandingan

\section{PENDAHULUAN}

Pembangunan yang dilakukan dengan teknologi sederhana maupun tinggi tidak pernah luput dari adanya resiko kecelakaan kerja. Pada tahun 2017 angka kecelakaan kerja mengalami penurunan dibandingkan tahun 2016, tercatat terjadi sebanyak 80.393 kasus kecelakaan kerja di Indonesia. Selain itu perusahaan yang menerapkan Sistem Manajemen K3 meningkat 69,1\% dibandingkan tahun 2016, yakni diangka 1.221 perusahaan (Kementerian Ketenagakerjaan, 2018).

Keselamatan kerja mengandung arti cara seseorang untuk menjaga diri atau orang lain karena beban kerja yang ada di lapangan mengharuskan seorang pekerja mendapat perlindungan tersebut agar mereka dapat bekerja secara maksimal. Untuk mengurangi kecelakaan kerja maka perusahaan wajib menerapkan sistem keselamatan kerja yang baik dan tegas. Maka perlu diterapkan Sistem Manajemen Keselamatan dan Kesehatan Kerja (SMK3) di dalam sebuah proyek untuk meningkatkan perlindungan kepada pekerja (PP nomor 50 tahun 2012).

Keselamatan dan kesehatan kerja (K3) merupakan suatu pemikiran dan upaya untuk menjamin keutuhan dan kesempurnaan baik jasmani maupun rohani tenaga kerja pada khususnya, dan manusia pada umumnya, hasil karya dan budaya untuk menuju masyarakat adil dan makmur (Mangkunegara, 2002).

Keselamatan kerja merupakan rangkaian usaha untuk mewujudkan suasana kerja yang aman dan tentram bagi para karyawan atau pekerja yang bekerja pada perusahaan yang bersangkutan (Suma'mur, 2001).

Pelaksanaan keselamatan dan kesehatan kerja yang baik diperlukan untuk meminimalkan kecelakaan dalam bekerja khususnya pada proyek konstruksi. Oleh karena itu perlu adanya penelitian tentang tingkat pelaksanaan keselamatan dan kesehatan kerja dan fasilitas-fasilitas keselamatan kerja di proyek konstruksi agar kedepannya dapat dilakukan tindakan-tindakan untuk mengurangi kecelakaan kerja pada proyek konstruksi.

\section{METODE PENELITIAN}

Metode yang digunakan adalah metode survai, dengan pengumpulan melalui kuesioner. Teknik pengambilan sampel menggunakan metode NonProbability Sampling dengan teknik Purposive Sampling, yakni sampel atau responden yang dipilih berdasarkan kriteria jabatan dan pemahaman materi K3 di lapangan.

Lokasi penelitian dilakukan di 3 proyek konstruksi gedung yang berbeda di Kota Surabaya,

1. Proyek Pembangunan Apartement BeSS Mansion,

Kota Surabaya. Terletak di Jalan Raya Jemursari no.15, Surabaya.

2. Proyek Pembangunan Gedung Ciputra World, Kota Surabaya. Terletak di Jalan Raya Mayjend

Sungkono, Surabaya

3. Proyek Pembangunan Gedung C dan Masjid

Kampus 2 STIE Perbanas, Kota Surabaya. Terletak

di Jalan Wonorejo Utara no.16, Surabaya.

Penelitian ini menggunakan 2 tahapan kuesioner yang ditujukan kepada responden adalah sebagai berikut:

a) Kuesioner jenis check list dengan metode skala Guttman, yaitu kuesioner jenis check-list yang menggunakan jawaban bersifat jelas, tegas, dan konsisten, seperti: ya - tidak, sesuai - tidak sesuai, benar - salah, positif - negatif, dan lain sebagainya (Riduwan, 2003). Kuesioner berisi 166 poin pertanyaan mengenai Sistem Manajemen K3 mengacu pada Pedoman Daftar 
Periksa Audit Penilaian Penerapan Sistem Manajemen K3 Permenaker nomor 5 tahun 1996 dengan jawaban "sesuai" dan "tidak sesuai". Kriteria pencapian penerapan seperti pada tabel 1.

Tabel 1. Tingkat Pencapaian Penerapan SMK3

\begin{tabular}{cc}
\hline \multicolumn{2}{c}{ Tingkat Pencapaian Penerapan } \\
\hline $0-59 \%$ & Kurang \\
$60-84 \%$ & Baik \\
$85-100 \%$ & Memuaskan \\
\hline Sumber:Permenaker
\end{tabular}

Sumber : Permenaker no.5 thn 1996

b) Kuesioner penelitian kelengkapan fasilitas Keselamatan dan Kesehatan Kerja dengan menggunakan metode skala likert, yaitu kuesioner yang menggunakan pengukuran sikap, pendapat dan persepsi dari responden tentang suatu kejadian yang variabelnya telah ditetapkan secara spesifik oleh peneliti (Riduwan, 2003). Adapun skala pengukurannya yaitu :

$1=$ Jika tidak tersedia,

2 = jika tersedia, tidak layak, dan tidak lengkap

$3=$ jika tersedia, layak, dan tidak lengkap

$4=$ jika tersedia, tidak layak, dan lengkap

$5=$ jika tersedia, layak, dan lengkap

Dari kedua analisis tersebut diperoleh hubungan antara penerapan sistem manajemen K3 dengan kelengkapan fasilitas K3 yang digunakan pada saat pelaksanaan kegiatan proyek. Karena kedua hal tersebut saling mempengaruhi, misalnya saja fasilitas K3 yang digunakan tidak lengkap atau pun tidak layak, maka dapat mempengaruhi nilai dari penerapan sistem manajemen K3 pada proyek tersebut

\section{HASIL DAN PEMBAHASAN \\ Profil Responden}

Data responden yang diambil adalah nama responden, nama instansi, pendidikan terakhir, jabatan dalam pekerjaan, dan lama bekerja. Responden didominasi lulusan Strata 1 (S1) dengan lama bekerja antara 1-5 tahun. Penjabaran dapat dilihat pada Gambar1,2, dan 3 :

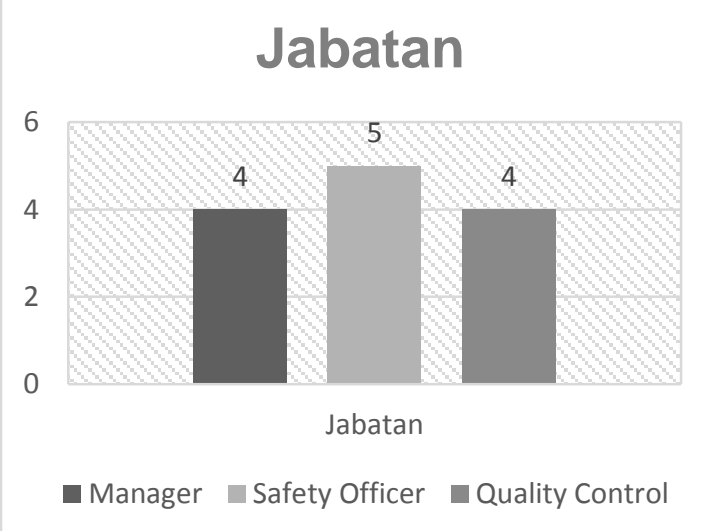

Gambar 1 Jabatan Responden Sumber : Hasil Olahan

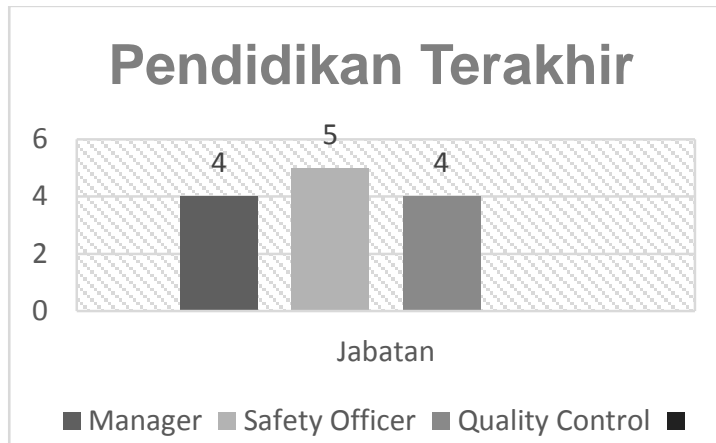

Gambar 2 Pendidikan Responden

Sumber : Hasil Olahan

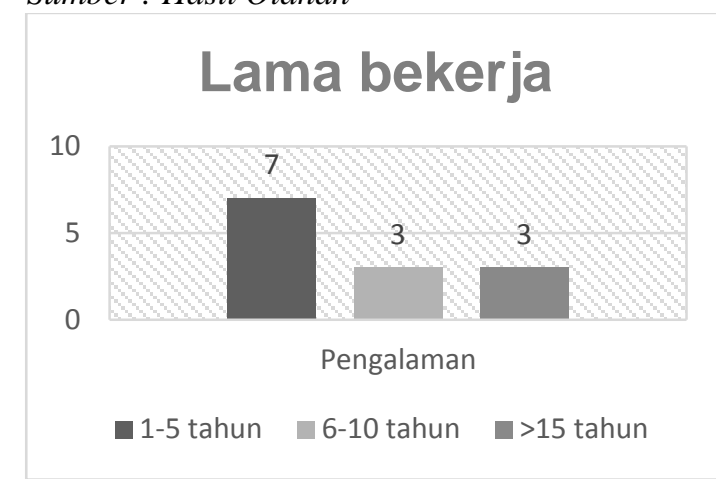

Gambar 3 Lama Bekerja Responden

Sumber : Hasil Olahan

\section{Penerapan Sistem Manajemen K3}

Penerapan SMK3 di audit berdasarkan Permenaker no.5 tahun 1996. Perhitungan check list ini menggunakan rumus :

$\frac{\sum \text { Nilai Pemenuhan }}{166 \text { kriteria }}$ X 100\% $=$ Persentase Pencapaian

1. Proyek Apartemen BeSS Mansion

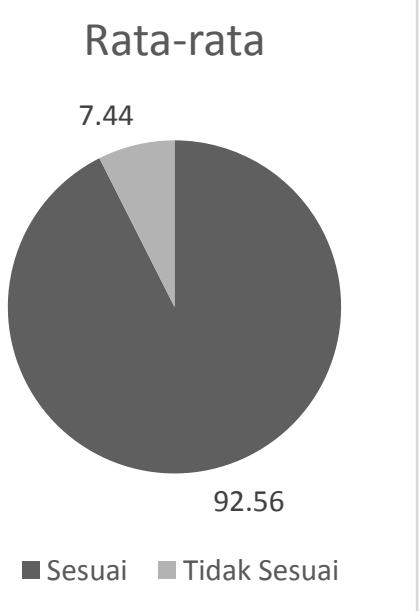

Gambar 4 Mean Pencapaian Penerapan SMK3 di Proyek BeSS Mansion Sumber : Hasil Olahan

Pada proyek Apartemen BeSS Mansion didapat nilai rata-rata memuaskan yaitu 92,56\%, namun ada beberapa kertidaksesuaian yang berpotensi dapat berdampak kurang baik bagi jalannya proyek. Adapun beberapa kriteria yang tidak sesuai dengan 
Permenaker no.5 tahun 1996 yang sama dari ketiga responden tersebut.

- Tentang Manual SMK3 :

- Manual SMK3 meliputi kebijakan, tujuan, rencana, prosedur SMK3, instruksi kerja, formulir, catatan dan tanggung jawab serta wewenang tanggung jawab K3 untuk semua tingkatan dalam perusahaan

- Terdapat manual khusus yang berkaitan dengan produk, proses, atau tempat kerja tertentu

- Manual K3 mudah didapat oleh semua personil dalam perusahaan sesuai kebutuhan

2. Proyek Gedung Ciputra World

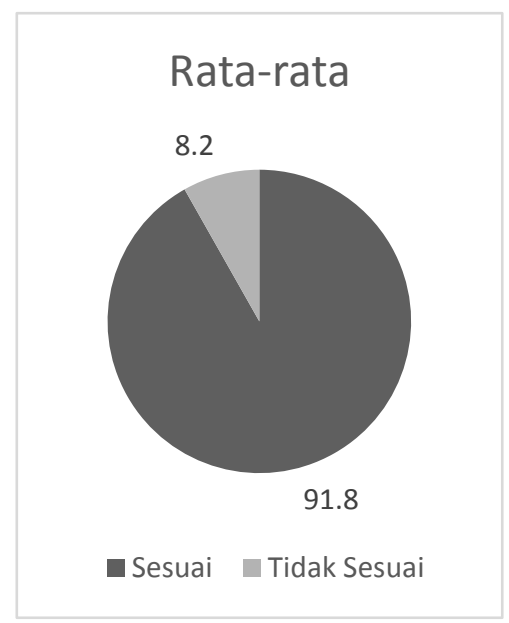

Gambar 5 Mean Pencapaian Penerapan SMK3 di Proyek Ciputra World

Sumber : Hasil Olahan

Pada proyek Gedung Ciputra World didapat nilai rata-rata memuaskan yaitu $91,80 \%$, namun ada beberapa kertidaksesuaian yang berpotensi dapat berdampak kurang baik bagi jalannya proyek. Adapun beberapa kriteria yang tidak sesuai dengan Permenaker no.5 tahun 1996 yang sama dari kelima responden tersebut.

- Perubahan dan Modifikasi Dokumen

- Terdapat sistem untuk membuat, menyetujui perubahan terhadap dokumen K3

- Pemeriksaan Bahaya

- Alat dipelihara dan dikalibrasi oleh petugas atau pihak yang berkompeten dan berwenang dari dalam dan/atau luar perusahaan

- Sistem Pengangkutan, Penyimpanan dan Pembuangan

- Terdapat prosedur yang menjamin bahwa bahan dibuang dengan cara yang aman dan sesuai dengan peraturan perundang-undangan

- Pengendalian Bahan Kimia Berbahaya (BKB)

- Perusahaan telah mendokumentasikan dan menerapkan prosedur mengenai penyimpanan, penanganan, dan pemindahan BKB sesuai dengan peraturan peundang-undangan, tandar dan pedoman teknis yang relevan

- Terdapat lembar data keselamatan BKB meliputi keterangan mengenai keselamatan bahan sebagaimana diatur pada peraturan perundang-undangan dan dengan mudah dapat diperoleh

- Pengembangan Keterampilan dan Kemampuan

- Jenis pelatihan K3 yang dilakukan harus disesuaikan dengan kebutuhan untuk pengendalian potensi bahaya

- Pelatihan dilakukan oleh orang atau badan yang berkompeten dan berwenang sesuai peruindang-undangan

- Terdapat fasilitas dan sumber daya memadai untuk pelaksanaan pelatihan yang efektif

- Pengusaha atau pengurus mendokumentasikan dan menyimpan seluruh catatan pelatihan

- Anggota manajemen eksekutif dan pengurus berperan serta dalam pelatihan yang mencakup penjelasan tentang kewajiban hokum dan prinsip-prinsip serta pelaksanaan K3

- Pelatihan diberikan kepada tenaga kerja apabila di tempat kerja terjadi perubahan sarana produksi atau proses

- Pengusaha atau pengurus memberikan pelatihan penyegaran kepada semua tenaga kerja

- Terdapat prosedur yang menetapkan persyaratan untuk memberikan briefing kepada pengunjung dan mitra kerja guna menjamin K3

- Perusahaan mempunyai sistem yang menjamin kepatuhan terhadap persyaratan lisensi atau kualifikasi sesuai dengan perundang-undangan untuk melaksanakan tugas khusus, melaksanakan pekerjaan atau mengoperasikan peralatan

3. Proyek Gedung C dan Masjid Kampus Perbanas II

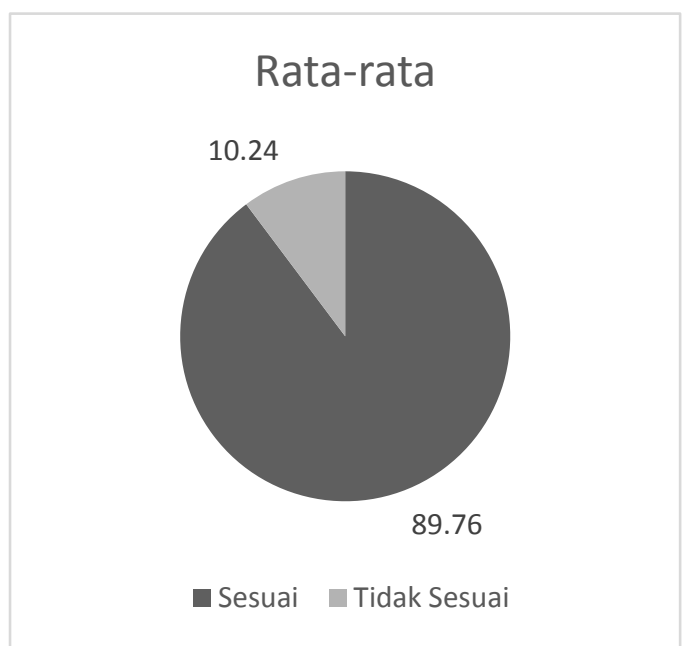

Gambar 6 Mean Pencapaian Penerapan SMK3 di Proyek Kampus Perbanas II

Sumber : Hasil Olahan

Pada proyek Kampus Perbanas didapat nilai ratarata memuaskan yaitu $89,76 \%$, namun ada beberapa kertidaksesuaian yang berpotensi dapat berdampak kurang baik bagi jalannya proyek. Adapun beberapa kriteria yang tidak sesuai dengan 
Permenaker no.5 tahun 1996 yang sama dari kelima responden tersebut.

- Kemampuan Telusur Produk

- Semua produk yang digunakan dalam proses produksi dapat diidentifikasi diseluruh tahapan produksi dan instalasi, jika terdapat potensi masalah K3

- Terdapat prosedur yang terdokumentasi untuk penelusuran produk yang telah terjual, jika terdapat potensi masalah $\mathrm{K} 3$ didalam penggunaannya

- Pengendalian Bahan Kimia Berbahaya (BKB)

- Perusahaan telah mendokumentasikan dan menerapkan prosedur mengenai penyimpanan, penanganan, dan pemindahan BKB sesuai dengan peraturan peundang-undangan, tandar dan pedoman teknis yang relevan

- Terdapat lembar data keselamatan BKB meliputi keterangan mengenai keselamatan bahan sebagaimana diatur pada peraturan perundang-undangan dan dengan mudah dapat diperoleh

- Terdapat sistem untuk mengidentifikasi dan pemberian label secara jelas pada BKB

- Rambu peringatan bahaya terpasang sesuai dengan persyaratan perundangan

- Penanganan BKB dilakukan oleh pihak yang berkompeten atau berwenang

- Catatan K3

- Terdapat prosedur yang menentukan persyaratan untuk menjaga kerahasiaan catatan

- Catatan kompensasi kecelakaan dan rehabilitasi kesehatan tenaga kerja dipelihara

\section{Kelengkapan Alat Pelindung Diri dan Fasilitas K3}

Penilaian terhadap Alat Pengaman Diri dan Fasilitas K3 dalam 3 studi kasus mendapatkan hasil yang bervariasi dari masing-masing responden pada setiap proyek. Hal ini karena kebijakan, dan faktor-faktor lain yang mempengaruhi dari proyek yang diteliti. Perhitungan persentase dapat dihitung dengan rumus :

$\frac{\text { total skor yang didapat }}{\sum \text { skor maksimal }}$
kelengkapan

Tabel 2 Persentase Kelengkapan Fasilitas K3

\begin{tabular}{lc}
\hline Nama Proyek & $\begin{array}{l}\text { Kelengkapan } \\
\text { Fasilitas K3 (\%) }\end{array}$ \\
\hline Apartemen BeSS Mansion & 95,55 \\
Gedung Ciputra World & 93,67 \\
Gedung C dan Masjid Perbanas & 73,33 \\
II & \\
\hline
\end{tabular}

Sumber: Hasil Olahan

\section{Hubungan Penerapan SMK3 dengan Kelengkapan Fasilitas K3}

Dari hasil analisis data kuesioner penerapan sistem manajemen K3 dan kelengkapan fasilitas K3 dapat direkap persentase angka rata-rata di ketiga proyek yang dapat dilihat pada tabel 3 .
Tabel 3 Rekapitulasi Persentase Kuesioner

$\begin{array}{lll} & \text { Penerapan } & \text { Kelengkapan } \\ \text { Nama Proyek } & \text { SMK3 (\%) } & \text { Fasilitas K }\end{array}$
(\%)

\begin{tabular}{lcc} 
Apartemen BeSS & 92,56 & 95,55 \\
$\begin{array}{l}\text { Mansion } \\
\text { Gedung Ciputra World }\end{array}$ & 91,80 & 93,67 \\
$\begin{array}{l}\text { Gedung C dan Masjid } \\
\text { Perbanas II }\end{array}$ & 89,76 & 73,33 \\
\hline
\end{tabular}

Sumber : Hasil Olahan

Berdasarkan tabel 3 kelengkapan fasilitas K3 mempengaruhi besarnya nilai penerapan K3 di proyek, hal tersebut dapat dikarenakan pentingnya alat pelindung diri maupun fasilitas pengaman proyek guna menunjang keselamatan pekerja di lapangan disamping dengan baiknya manajemen K3 yang direncanakan dan diimplementasikan di proyek konstruksi gedung.

\section{Perbandingan Penerapan Sistem Manajemen K3 dan Kelengkapan Fasilitas K3 di ketiga proyek}

Pada tabel 2 dapat dilihat bahwa adanya perbedaan persentase di ketiga proyek, jika ditinjau lebih detail, pada analisis data kuesioner ada perbedaan pada poin-poin penerapan SMK3 yang tidak sesuai dengan Permenaker no.5 tahun 1996, dan juga pada kelengkapan fasilitas K3 di masing-masing proyek. Perbandingan ketidaksesuaian penerapan K3 dapat dilihat di tabel 4.

Tabel 4 Ketidaksesuaian Penerapan SMK3

\begin{tabular}{|c|c|c|c|}
\hline Kriteria & $\begin{array}{c}\text { Apartement } \\
\text { BeSS } \\
\text { Mansion } \\
\text { (A) }\end{array}$ & $\begin{array}{c}\text { Gedung } \\
\text { Ciputra } \\
\text { World } \\
\text { (B) }\end{array}$ & $\begin{array}{c}\text { Gedung } \\
\text { C dan } \\
\text { Masjid } \\
\text { Perbanas } \\
\text { II }(\text { C })\end{array}$ \\
\hline Manual SMK3 & $\begin{array}{l}\text { Tidak } \\
\text { Sesuai }\end{array}$ & $\sqrt{ }$ & $\sqrt{ }$ \\
\hline $\begin{array}{l}\text { Perubahan dan } \\
\text { Modifikasi } \\
\text { Dokumen }\end{array}$ & $\sqrt{ }$ & $\begin{array}{c}\text { Tidak } \\
\text { Sesuai }\end{array}$ & $\sqrt{ }$ \\
\hline $\begin{array}{l}\text { Kemampuan } \\
\text { Telusur Produk }\end{array}$ & $\sqrt{ }$ & $\sqrt{ }$ & $\begin{array}{l}\text { Tidak } \\
\text { Sesuai }\end{array}$ \\
\hline $\begin{array}{l}\text { Sistem } \\
\text { Pengangkutan, } \\
\text { Penyimpanan, } \\
\text { dan } \\
\text { Pembuangan }\end{array}$ & $\sqrt{ }$ & $\begin{array}{l}\text { Tidak } \\
\text { Sesuai }\end{array}$ & $\sqrt{ }$ \\
\hline Catatan K3 & $\sqrt{ }$ & $\sqrt{ }$ & $\begin{array}{l}\text { Tidak } \\
\text { Sesuai }\end{array}$ \\
\hline $\begin{array}{l}\text { Pengendalian } \\
\text { BKB }\end{array}$ & $\sqrt{ }$ & $\begin{array}{l}\text { Tidak } \\
\text { Sesuai }\end{array}$ & $\begin{array}{l}\text { Tidak } \\
\text { Sesuai }\end{array}$ \\
\hline $\begin{array}{l}\text { Pengembangan } \\
\text { Keterampilan } \\
\text { dan } \\
\text { Kemampuan }\end{array}$ & $\sqrt{ }$ & $\begin{array}{l}\text { Tidak } \\
\text { Sesuai }\end{array}$ & $\sqrt{ }$ \\
\hline
\end{tabular}

Sumber : Hasil Olahan 
Berdasarkan Tabel 4, dapat diambil beberapa faktor yang menjadikan kriteria yang tidak sesuai dan mempengaruhi perbedaan yang terjadi di lapangan.

1. Faktor Perencanaan SMK3

Perencanaan manajemen K3 merupakan awal dari berjalannya sistem K3 di lapangan, dengan adanya manajemen yang baik perlu diikuti juga dengan implementasi rencana $\mathrm{K} 3$ demi menjamin keselamatan pekerja di lapangan

\section{Faktor Perusahaan Kontraktor}

Badan usaha kontraktor yang menjalankan proyek juga berpengaruh terhadap penerapan SMK3 maupun kelengkapan fasilitas yang dimiliki. Proyek A dijalankan oleh kontraktor BUMN atau milik pemerintah, sedangkan proyek $\mathrm{B}$ dan $\mathrm{C}$ merupakan perusahaan milik swasta kelas tinggi dan menengah. Meski begitu penerapan SMK3 dan kelengkapan fasilitas K3 yang dimiliki perusahaan swasta ini cukup memuaskan, namun perlu sedikit pembenahan agar tetap menjamin keselamatan pekerja di lapangan

Tabel 5 Perbandingan Ketidaksesuaian APD dan Fasilitas K3

\begin{tabular}{|c|c|c|c|}
\hline $\begin{array}{c}\text { APD dan } \\
\text { Fasilitas } \mathrm{K} 3 \\
\text { tidak sesuai }\end{array}$ & $\begin{array}{c}\text { Apartem } \\
\text { ent BeSS } \\
\text { Mansion } \\
(A)\end{array}$ & $\begin{array}{c}\text { Gedung } \\
\text { Ciputra } \\
\text { World }(B)\end{array}$ & $\begin{array}{c}\text { Gedung C } \\
\text { dan } \\
\text { Masjid } \\
\text { Perbanas } \\
\text { II }(C) \\
\end{array}$ \\
\hline Gloves & $\sqrt{ }$ & $\sqrt{ }$ & $\begin{array}{c}\text { Tidak } \\
\text { Lengkap }\end{array}$ \\
\hline Rompi & $\sqrt{ }$ & $\begin{array}{l}\text { Tidak } \\
\text { Layak }\end{array}$ & $\begin{array}{c}\text { Tidak } \\
\text { Lengkap }\end{array}$ \\
\hline Masker & $\sqrt{ }$ & $\begin{array}{l}\text { Tidak } \\
\text { Layak }\end{array}$ & $\begin{array}{c}\text { Tidak } \\
\text { Lengkap }\end{array}$ \\
\hline Body Harness & $\sqrt{ }$ & $\begin{array}{c}\text { Tidak } \\
\text { Lengkap }\end{array}$ & $\sqrt{ }$ \\
\hline $\begin{array}{l}\text { Rambu- } \\
\text { rambu }\end{array}$ & $\sqrt{ }$ & $\sqrt{ }$ & $\begin{array}{c}\text { Tidak } \\
\text { Lengkap }\end{array}$ \\
\hline Spanduk K3 & $\sqrt{ }$ & $\sqrt{ }$ & $\begin{array}{c}\text { Tidak } \\
\text { Lengkap }\end{array}$ \\
\hline $\begin{array}{l}\text { Alarm } \\
\text { Peringatan }\end{array}$ & $\sqrt{ }$ & $\begin{array}{l}\text { Tidak } \\
\text { Layak }\end{array}$ & Tidak Ada \\
\hline $\begin{array}{l}\text { Lampu } \\
\text { Peringatan }\end{array}$ & $\begin{array}{l}\text { Tidak } \\
\text { Layak }\end{array}$ & $\sqrt{ }$ & $\begin{array}{c}\text { Tidak } \\
\text { Lengkap }\end{array}$ \\
\hline
\end{tabular}

Sumber : Hasil Olahan

Berdasarkan Tabel 5, dapat diambil beberapa faktor yang menjadikan fasilitas K3 dan APD yang kurang lengkap dan layak, dan dapat mempengaruhi perbedaan yang terjadi di lapangan.

1. Faktor Kesiapan Manajemen

Kesiapan dari manajemen yang dimaksudkan adalah memfasilitasi pekerja dengan Alat Pelindung Diri (APD) yang layak dan juga lengkap, serta mengecek fasilitas pengaman proyek yang mereka miliki apakah berfungsi dengan baik atau tidak

2. Faktor Kesadaran Manajemen

Kesadaran yang dimaksud adalah pihak manajemen sadar akan keselamatan para pekerja, sehingga mereka perlu memperhatikan alat-alat pelindung diri pekerja apakah sudah layak, dan fasilitas K3 yang ada di proyek seperti spanduk, rambu, alarm, dan lain sebagainya apakah sudah lengkap dang berfungsi sebagaimana mestinya

\section{UCAPAN TERIMAKASIH}

Terima kasih atas kerjasamanya dalam penelitian kepada pihak manajemen PT Adhi Persada Gedung, PT Tatamulia Nusantara Indah, dan PT Tajimaka

\section{KESIMPULAN DAN SARAN \\ Kesimpulan}

Penelitian ini dapat disimpulkan sebagai berikut :

1. Di proyek konstruksi gedung yang diteliti sudah menerapkan Sistem Manajemen K3 dengan baik, tetapi belum $100 \%$. Berdasarkan Permenaker no.5 tahun 1996, untuk proyek Apartemen BeSS Mansion nilai rata-rata pencapaian adalah $92,56 \%$ dengan nilai memuaskan, proyek Gedung Ciputra World nilai rata-rata pencapaian $91,80 \%$ dengan nilai memuaskan, dan proyek Gedung $\mathrm{C}$ dan Masjid Kampus Perbanas II nilai rata-rata pencapaian $89,76 \%$ dengan nilai memuaskan.

2. Nilai kelengkapan Alat Pelindung Diri (APD) dan failitas K3 pada 3 proyek yang diteliti menunjukkan angka persentase yang cukup baik, pada proyek Apartemen BeSS Mansion mendapat nilai rata-rata $95,55 \%$, proyek Gedung Ciputra World dengan nilai rata-rata 93,67\%, dan pada proyek Gedung $\mathrm{C}$ dan Masjid Kampus Perbanas II mendapat nilai rata-rata $73,33 \%$.

3. Perbandingan antara ketiga proyek menunjukkan bahwa perbedaan tersebut dipengaruhi oleh 4 faktor yang terjadi di lapangan, faktor-faktor tersebut adalah :

1. Faktor Perencanaan

2. Faktor Perusahaan Kontraktor terkait

3. Faktor Kesiapan Manajemen

4. Faktor Kesadaran Manajemen

\section{Saran}

Dari hasil analisis data, maka disarankan untuk menyempurnakan Sistem Manajemen K3 serta Kelengkapan APD dan fasilitas K3. Sebagai solusi, antara lain dengan cara :

1. Memastikan adanya SDM dalam bidang SMK3 yang memadai sejak masa perencanaan/persiapan proyek

2. Melakukan evaluasi kembali yang sudah dilaksanakan apakah sudah sesuai dengan rencana, serta mengkoordinasikan guna menyempurnakan SMK3

3. Meningkatkan partisipasi konsultan K3 dengan melakukan sosialisasi kepada pekerja guna mengoptimalkan fungsi safety di lapangan

4. Mengevaluasi peralatan Alat Pelindung Diri dan fasilitas K3 yang ada di lapangan, guna memastikan fungsi yang layak dan lengkap 
6. DAFTAR PUSTAKA

[1] Kementerian Ketenagakerjaan. 2018. Kemenaker Klaim Kasus Kecelakaan Kerja Tahun 2017 Menurun,(Online),

(https://nasional.republika.co.id, Diakses 9 September 2018).

[2] Mangkunegara, Anwar Prabu. 2002. Manajemen Sumber Daya Manusia.Bandung: PT. Remaja Rosda Karya.

[3] Peraturan Menteri Tenaga Kerja nomor 5 tahun 1996 tentang Sistem Manajemen Keselamatan dan Kesehatan Kerja. Jakarta: Menteri Tenaga Kerja Republik Indonesia

[4] Peraturan Pemerintah Republik Indonesia nomor 50 tahun 2012 tentang Penerapan Sistem Manajemen Keselamatan dan Kesehatan Kerja. Jakarta: Departemen Pekerjaan Umum

[5] Riduwan. 2003. Dasar - Dasar Statistika. Bandung: Alfabeta.

[6] Suma'mur. 2001. Keselamatan Kerja dan Pencegahan Kecelakaan. Jakarta: CV. Haji Masagung. 


\title{
ANALISIS PADA PEKERJAAN GALIAN UNTUK MENCARI PRODUKTIVITAS DAN KOMBINASI ALAT BERAT DI PROYEK PEMBANGUNAN REFINERY DI PT. SALIM IVOMAS PRATAMA, TBK.
}

\author{
Mauliddiyah Ainurrizki', Siti Choiriyah², Theresia MCA ${ }^{3}$ \\ ${ }^{1}$ Jurusan Teknik Sipil, Fakultas Teknik Sipil dan Perencanaan, Institut Teknologi Adhi Tama Surabaya \\ 2,3 Jurusan Teknik Sipil, Fakultas Teknik Sipil dan Perencanaan, Institut Teknologi Adhi Tama Surabaya \\ Email : $\underline{\text { siti.choiriyah@itats.ac.id }}$
}

\begin{abstract}
ABSTRAK Pekerjaan tanah dalam suatu proyek pembangunan gedung merupakan salah satu bagian yang sangat penting. Pekerjaan tanah disini adalah pekerjaan galian dan pengangkutan. Untuk mempermudah dan mempercepat pekerjaan tanah diperlukan bantuan alat yaitu alat berat. Pada proyek pembangunan refinery di Perak barat, Surabaya memiliki akses jalan yang sempit, sehingga mobilisasi alat berat terbatas. Maksud dari penelitian ini adalah menghitung jumlah produktivitas alat berat dalam pekerjaan pembangunan pabrik dan tujuan dari penelitian ini adalah untuk mengetahui kombinasi alat berat yang optimal. Untuk mengetahui produktivitas alat berat khususnya excavator dan dump truck dilakukan dengan metode perhitungan berdasarkan data analisa di lapangan. Hasil dari perhitungan maka diperoleh produktivitas/kombinasi alat berat. Hasil perhitungan alat berat pada pekerjaan galian di proyek pembangunan refinery PT. Salim Ivomas Pratama, Tbk Kombinasi yang efisien yaitu Kombinasi keempat terdiri dari 1 unit Shovel, 1 unit excavator dengan unit excavator dengan jenis/tipe Long Arm 320 dengan kapasitas bucket $0,90 \mathrm{~m}^{3}$ dan 10 unit dump truck jenis/tipe Hino dutro $130 \mathrm{HD}$ dengan kapasitas $10 \mathrm{~m}^{3}$. Total produktivitas untuk shovel didapat dari 32 $\mathrm{m}^{3}$ produktivitas/jam x 8 jam kerja/hari $=256 \mathrm{~m}^{3} /$ hari, Total produktivitas untuk excavator didapat dari $32,8 \mathrm{~m}^{3}$ produktivitas/jam x 8 jam kerja/hari $=262,4 \mathrm{~m}^{3} /$ hari dan total produktivitas dump truck didapat dari $5,16 \mathrm{~m}^{3}$ produktivitas/jam x 8 jam kerja/hari $=41,3$ m³/hari. Kombinasi keempat menghasilkan waktu 25 hari.
\end{abstract}

Kata kunci : galian tanah, produktivitas, excavator, dumptruck, kombinasi

\section{PENDAHULUAN}

Pada proyek-proyek konstruksi saat ini, pengunaan alat berat merupakan hal terpenting. Karena dalam setiap pembangunan proyek menggunakan alat berat dengan berbagai fungsi, jenis, bentuk dan merk. Dalam pembangunan proyek-proyek kostruksi tersebut penggunaan alat berat berperan penting sebagai pengaruh dalam finansial dan kelangsungan pekerjaan di proyek.

Pematangan atau persiapan lahan akan terjadi pada setiap proyek konstruksi. Pada proses penyelesaiannya dibutuhkan bantuan alat berat untuk mempermudah proses pekerjaan di lapangan. Pemilihan alat berat tersebut tergantung pada karakteristik masing-masing alat dan keadaan di lapangan. Hal ini diperlukan agar alat tersebut dapat bekerja sesuai dengan rencana yang tepat waktu dan pekerjaan yang telah ditetapkan. Adapun pekerjaan tanah meliputi dari pekerjaan galian dan pekerjaan timbunan. Pekerjaan galian tanah dikerjakan dengan bantuan alat berat. Dalam pelaksanaan pekerjaan galian material, digunakan alat berat seperti excavator, dumptruck dan shovel.

Menurut Rostyanti, (2008) Alat berat memiliki banyak jenisnya, sehingga pemilihan alat berat harus disesuaikan dengan kebutuhan di lapangan. Pemilihan alat tepat akan berpengaruh terhadap produktivitas dan tercapainya target pekerjaan.
Produktivitas alat berat adalah kemampuan alat berat dalam menyelesaikan pekerjaan yang dihitung dalam satuan waktu, produktivitas alat berat tergantung pada kapasitas bucket, bucket faktor, cycletime dan faktor koreksi produksi.

Begitu pula pada Proyek Refinery PT. Salim Ivomas Pratama,Tbk berada di Jalan Tanjung Tembaga No. 2-6, Krembangan, Perak Barat, Surabaya dengan luas area $24 \times 6.6 \mathrm{~m}^{2}$ dan kedalaman galian $-4 \mathrm{~m}$. Jenis tanah pada lokasi galian adalah jenis tanah asli. Kendala yang dihadapi pada saat proses penggalian adalah akses jalan yang sempit sehingga mobilisasi alat berat terbatas. Pada proyek digunakan 5 jenis alat berat yaitu 1 shovel, 2 Excavator Komatsu Type PC 200 dan CAT PC 320 serta 2 Dumptruck Type Hino 130 HD dan Mitshubishi Fuso. Dengan kondisi akses jalan yang sempit akan mengakibatkan keterlambatan waktu jika semua alat berat digunakan secara bersamaan. Selain itu apabila alat berat digunakan secara bersamaan produktivitas alat berat kurang efektif. Sehingga dibutuhkan kombinasi walaupun dengan akses jalan yang sempit. Salah satunya dengan melakukan percobaan kombinasi alat berat pada proyek galian refinery PT. Salim Ivomas Pratama, Tbk untuk diperoleh nilai produktivitas yang paling efektif. 
METODOLOGI PENELITIAN

Berikut langkah - langkah untuk memulai penelitian

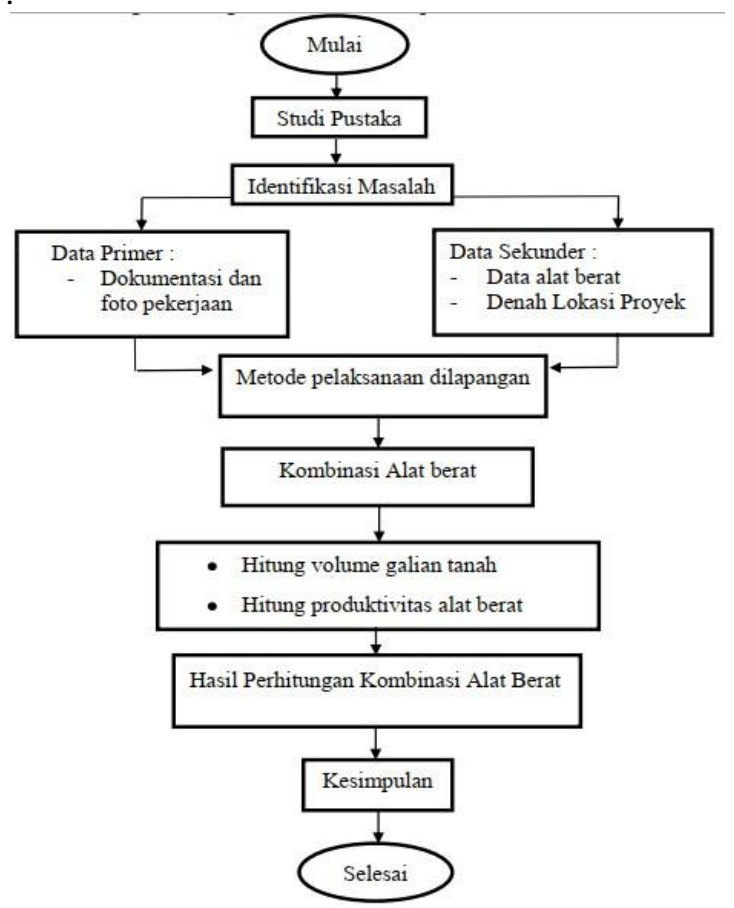

Gambar 1. Bagan Alir Penelitian

\subsection{Pengumpulan Data}

Sumber data yang diperoleh dalam penelitian mengenai produktivitas alat berat pada proyek pembangunan refinery PT. Salim Ivomas Pratama, Tbk antara lain :

1. Data Primer

2. Data Sekunder

\section{ANALISIS DAN PEMBAHASAN}

\section{Data Pekerjaan Proyek}

Pada pelaksanan proyek penggalian di PT. Salim Ivomas Pratama, Tbk yang berlokasi di Perak, Surabaya di peroleh data sebagai berikut :

a. Volume pekerjaan galian tanah

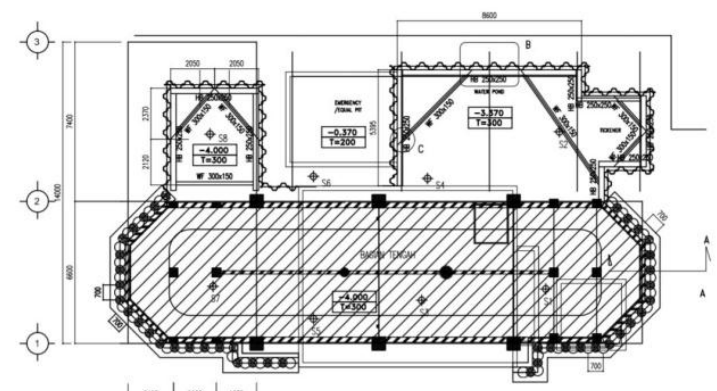

Sumber :PT. Lintech Duta Pratama,

Gambar 2. Area Galian Lahan

Volume 1 p.panjang $=\mathrm{p} \mathrm{x} 1 \mathrm{x} \mathrm{t}$

$=24 \times 6,6 \times 4=633,6 \mathrm{~m}^{3}$

Volume 11 trapesium

$=(1 / 2 \times(\mathrm{a}+\mathrm{b}) \times \mathrm{t}) \times 2$

$=(1 / 2 \times(2,350+6,6) \times 4) \times 2$
$=17,9 \times 2=35,8 \mathrm{~m}^{3}$

Voume total = volume $1+$ volume 11

$=633,6+35,8=669,4 \mathrm{~m}^{3}$

b. Jam kerja $\quad: 8$ jam/hari

c. Jenis tanah : tanah asli

\section{Perhitungan Produktivitas Alat Berat yang direncanakan}

4.3.1 Produksi Shovel

$>$ Produksi Shovel type A

Merk dan Type alat $=$ Komatsu PC 2000

Kapasitas bucket $=0,80 \mathrm{~m}^{3}$

Faktor bucket $(\mathrm{K})=0.8=0,8$

waktu gali $\quad=25$ detik

waktu buang $\quad=20$ detik

waktu swing $\quad=25$ detik

Kedalaman galian $\quad=4 \mathrm{~m}$

Tinggi slump $\quad=1 \mathrm{~m}$

Jam Kerja/Hari $\quad=8$ jam

- Volume tanah asli

- Waktu siklus $(\mathrm{Cm})$

$\mathrm{Cm}=$ waktu gali $+(2 \mathrm{x}$ waktu swing $)+$ waktu buang

$$
=25+(2 \times 20)+25=90 \text { detik }
$$

- Ketinggian optimum $=40 \% \times 4 \mathrm{~m}=1.6 \mathrm{~m}$

- Jenis tanah adalah lempung basah, maka didapat nilai $50-90 \%$, diambil $80 \%$

- Produktivitas untuk setiap jam (60 menit - jam : (90 detik / 60 detik - menit) $) \times 0,80 \mathrm{~m}^{3} \times 1 \mathrm{~m}=$ $32 \mathrm{~m} / \mathrm{jam}$

Produksi Excavator type A

Merk dan Type alat = Komatsu PC 200

$>$ Kapasitas bucket $\left(\mathrm{q}^{1}\right) \quad=0.75 \mathrm{~m}^{3}$

Faktor bucket $(\mathrm{K}) \quad=$ Waktu siklus

$>$ Waktu gali $=25$ detik

$>$ Waktu putar $\quad=20$ detik

Waktu buang = 25 detik

$>$ Waktu siklus $(\mathrm{Cm})$

$\mathrm{Cm}=$ waktu gali + waktu putar $\mathrm{x} 2+$ waktu buang $=25+(20 \times 2)+25$

$=90 \mathrm{detik} / \mathrm{siklus} \approx 1.50 \mathrm{menit} / \mathrm{siklus}$

Produksi per siklus ( q )

$\mathrm{q}=\mathrm{q} 1 x k$

$=0.75 \times 0.80$

$=0.6 \mathrm{~m} / \mathrm{siklus}$

Produksi Excavator per jam $9 \mathrm{~m}^{3} / \mathrm{jam}$ )

$\mathrm{Q}=\frac{q \times 60 \times E}{\mathrm{Cm}}$

$=\frac{0,6 \times 60 \times 0,83}{1,50}$

$=19,9 \mathrm{~m}^{3} / \mathrm{jam}$

Produksi Excavator type B 
Merk dan type alat $=$ Excavator Long arm pc 320

Kapasitas bucket $(\mathrm{q} 1) \quad=0,90 \mathrm{~m}^{3}$

Faktor bucket $(\mathrm{K})=0,80$

Waktu siklus

Waktu gali

$=30$ detik

Waktu isi

$=25$ detik

Waktu buang

$=30$ detik

Produksi per siklus $(\mathrm{q})=\mathrm{q} 1 \mathrm{x} \mathrm{k}$

$$
\begin{aligned}
& =0.90 \times 0.80 \\
& =0.72 \mathrm{~m}^{3} / \text { siklus }
\end{aligned}
$$

Waktu siklus ( $\mathrm{Cm}$ )

= waktu gali + waktu putar x 2 + waktu buang

$=30+(10 \times 2)+12$

$=62 \mathrm{detik} / \mathrm{siklus} \approx 1 \mathrm{menit} / \mathrm{siklus}$

Produksi per jam ( $\left.\mathrm{m}^{3} / \mathrm{jam}\right)$

$$
\begin{aligned}
\mathrm{Q} & =\frac{q \times 60 \times E}{C m} \\
& =\frac{0,72 \times 60 \times 0,76}{1} \\
& =32,8 \mathrm{~m}^{3} / \mathrm{jam}
\end{aligned}
$$

\section{$3 \quad$ Produksi Dumptruck}

\section{Produksi Dump Truck Tipe A}

- Merk dan model alat = Hino Dutro $130 \mathrm{H}$

- Jam kerja per hari = $\quad=8$ jam

- Kapasitas Dump Truck (V) = $10 \mathrm{~m}^{3}$

- Jarak pembuangan $\quad=17,5 \mathrm{~km}$

- Faktor efisiensi alat $(\mathrm{E})=0.75$

- Kapasitas pemuat (Excavator) $\mathrm{q} 1=0.83 \mathrm{~m}^{3}$

- Faktor bucket dari excavator $\mathrm{K}=0,9$

- Kecepatan rata-rata bermuatan (V1) $\mathrm{V} 1: 25 \mathrm{~km} / \mathrm{jam} \approx 334 \mathrm{~m} / \mathrm{menit}$

- Kecepatan rata-rata kosong (V2) $\mathrm{V} 2: 35 \mathrm{~km} / \mathrm{jam} \approx 500 \mathrm{~m} / \mathrm{menit}$

Mencari waktu siklus untuk mengetahui jangka waktu yang diperlukan alat-alat berat untuk menyelesaikan satu lingkaran operasi.

Waktu siklus

$>$ waktu damping (t1) : 0,60 menit

$>$ waktu ambil posisi (t2) : 0,80 menit

$>$ waktu pengisian $(\mathrm{t} 3) \quad: 17$ menit

$>$ waktu tempu isi (t4) : (L: V1) x 60

$:(17,5: 25) \times 60$

: 42 menit

waktu tempu kosong (t5) : (L : V2) x 60

$:(17,5: 35) \times 60$

: 30 menit

Sehingga total waktu siklus $(\mathrm{Cm})$ adalah

$$
\begin{aligned}
\mathrm{Cm} & =\mathrm{t} 1+\mathrm{t} 2+\mathrm{t} 3+\mathrm{t} 4+\mathrm{t} 5 \\
& =0,60+0,80+17+42+30 \\
& =91 \text { menit }
\end{aligned}
$$

Jumlah siklus excavator dalam mengisi Dump Truck adalah

$$
\begin{aligned}
& \mathrm{N}=\frac{\mathrm{q}}{\mathrm{a1} \mathrm{x} \mathrm{K}} \\
& =\frac{10}{0.83 \times 0.9}=13,38 \approx 14 \text { siklus }
\end{aligned}
$$

Produksi per siklus adalah

$$
\mathrm{Q}=\frac{C \times 60 \times E}{C m}
$$

$$
=\frac{10,45 \times 60 \times 0,75}{91}=5,16 \mathrm{~m}^{3} / \mathrm{jam}
$$

Produktivitas Dump Truck per jam $=5,16 \mathrm{~m}^{3} / \mathrm{jam}$

\section{Produksi Dump Truck Tipe B}

- Merk dan model alat = Mitsubishi Fuso

- Jam kerja per hari $\quad=8$ jam

- Kapasitas Dump Truck (V) $=12 \mathrm{~m}^{3}$

- Jarak pembuangan $(\mathrm{L}) \quad=500 \mathrm{~m}$

- Faktor efisiensi alat $(\mathrm{E}) \quad=0.75$

- Kapasitas pemuat (Excavator) $\mathrm{q} 1=0,97 \mathrm{~m}^{3}$

- Faktor bucket dari excavator $\mathrm{K}=0,80$

Kecepatan rata-rata bermuatan (V1) $\mathrm{V} 1: 30 \mathrm{~km} / \mathrm{jam} \approx 500 \mathrm{~m} / \mathrm{menit}$

Kecepatan rata-rata kosong (V2) $\mathrm{V} 2: 45 \mathrm{~km} / \mathrm{jam} \approx 750 \mathrm{~m} / \mathrm{menit}$

Mencari waktu siklus untuk mengetahui jangka waktu yang diperlukan alat-alat berat untuk menyelesaikan satu lingkaran operasi. Waktu siklus waktu damping (t1) $\quad: 0.60$ menit waktu ambil posisi (t2) $\quad: 0.60$ menit waktu pengisian (t3) : 20 menit waktu tempu isi (t4) : (L : V1) x 60

$$
:(17,5: 30) \times 60
$$

$$
\text { : } 35 \text { menit }
$$

waktu tempu kosong (t5) : (L : V2) x 60

$$
\begin{aligned}
& :(17,5: 45) \times 60 \\
& : 24 \text { menit }
\end{aligned}
$$

Sehingga total waktu siklus $(\mathrm{Cm})$ adalah

$$
\begin{aligned}
\mathrm{Cm} & =\mathrm{t} 1+\mathrm{t} 2+\mathrm{t} 3+\mathrm{t} 4+\mathrm{t} 5 \\
& =1+1+20+35+24 \\
& =81 \text { menit }
\end{aligned}
$$

Jumlah siklus excavator dalam mengisi Dump Truck adalah $\mathrm{N}=\underline{\mathrm{q}}$

$$
\begin{aligned}
& \mathrm{q} 1 \times \mathrm{K} \\
&=\frac{10}{0.83 \times 0.9}=13,38 \approx 14 \text { siklus }
\end{aligned}
$$

Produksi per siklus adalah

$$
\begin{aligned}
C & =n \times q 1 \times K \\
& =14 \times 0.83 \times 0.9 \\
& =10,45 \mathrm{~m}^{3}
\end{aligned}
$$

Maka produksi Dumb truck per jam adalah

$$
\begin{aligned}
C= & \frac{C \times 60 \times E}{C m} \\
& =\frac{10,45 \times 60 \times 0,75}{81}=5,80 \mathrm{~m}^{3} / \mathrm{jam}
\end{aligned}
$$


Tabel 1. Pendawalan Kombinasi Excavator A, B dan Dumb Truck A

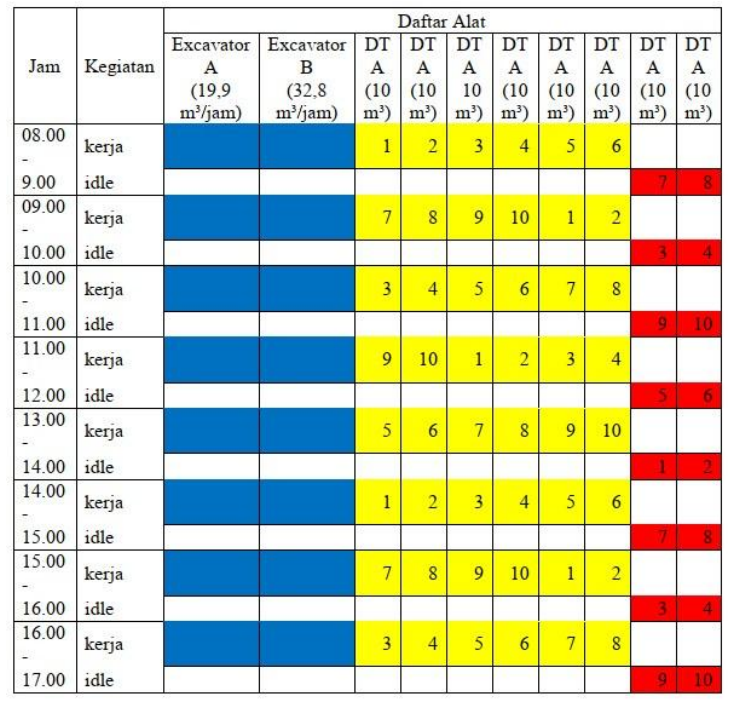

Tabel 2. Penjadwalan kombinasi excavator A, B dan Dumb Truck B

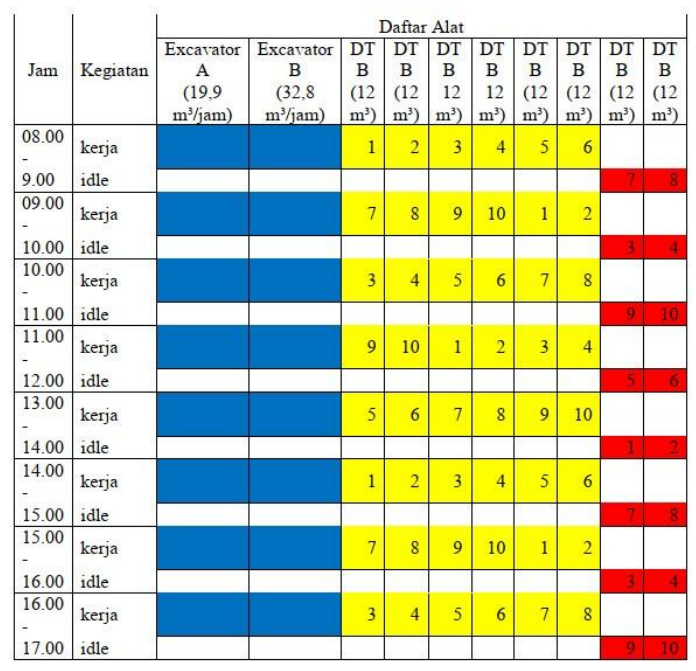

Tabel 3. Penjadwalan kombinasi excavator A, Shovel dan Dumb Truck A

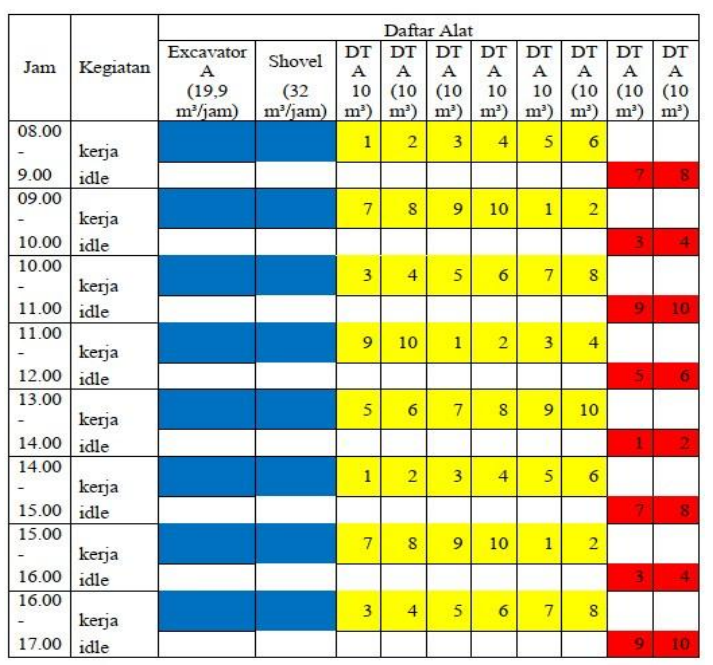

Tabel 4. Penjadwalan kombinasi excavator B, Shovel dan Dumb Truck A

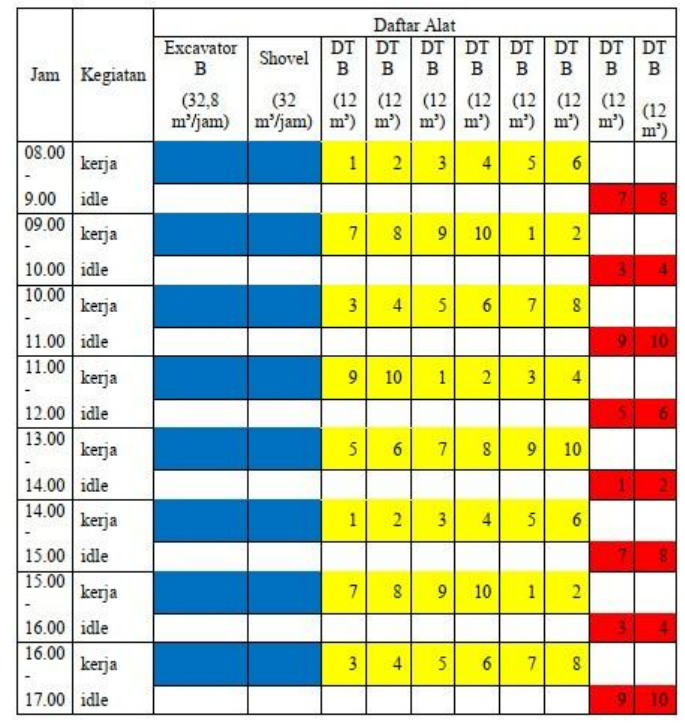

Tabel 5. Penjadwalan kombinasi excavator B, shovel dan dumb truck B

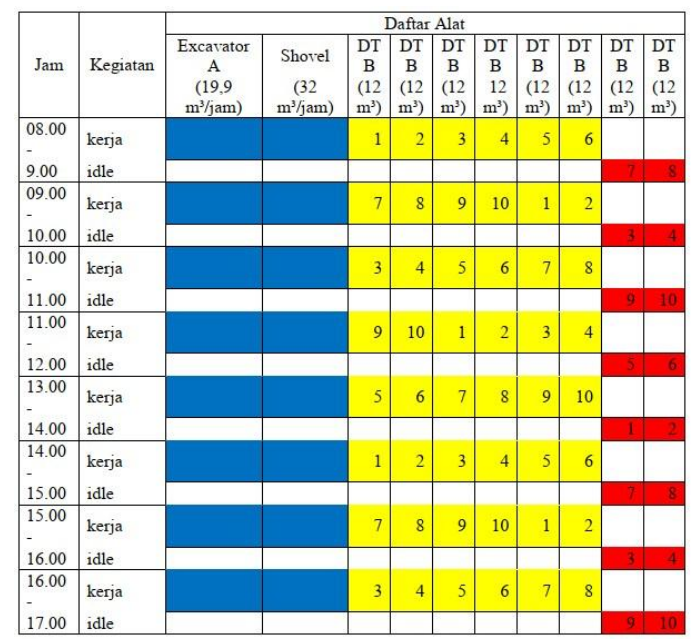

Tabel 6. Penjadwalan kombinasi excavator B dan dumb truck B

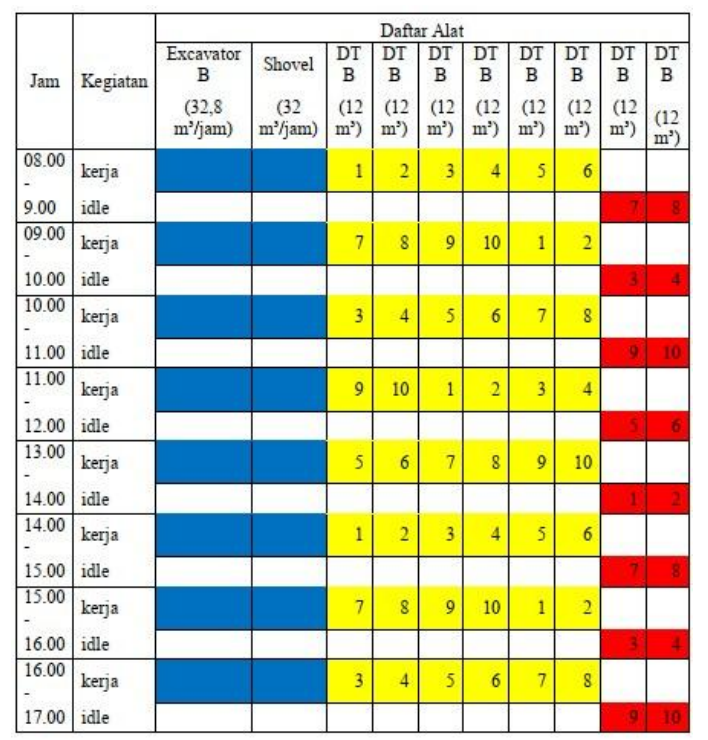




\section{KESIMPULAN}

Hasil perhitungan dari produktivitas alat berat antara produksi per jam dan produksi per hari pada proyek pembangunan refinery PT. Salim Ivomas Pratama, Tbk dapat diambil beberapa kesimpulan sebagai berikut :

1. Hasil produktivitas alat berat pada pekerjaan galian di proyek pembangunan refinery PT. Salim Ivomas Pratama, Tbk total produktivitas untuk excavator komatsu pc $75=40,5 \mathrm{~m}^{3} / \mathrm{jam}$, excavator komatsu pc $200=57,9 \mathrm{~m}^{3} / \mathrm{jam}$, untuk excavator Long Arm = $360,9 \mathrm{~m}^{3} / \mathrm{jam}$, produktivitas dump truck HINO dutro $130 \mathrm{HD}=224,6 \mathrm{~m}^{3} /$ hari, total produktivitas dump truck Mitsubishi FUSO $=381,5 \mathrm{~m}^{3} /$ hari, dan total produktivitas dump truck HINO fm 260 JD $=524,9$ $\mathrm{m}^{3} /$ hari.

2. Kombinasi keempat terdiri dari 1 unit Shovel, 1 unit excavator dengan unit excavator dengan jenis/tipe Long Arm 320 dengan kapasitas bucket $0,90 \mathrm{~m}^{3}$ dan 10 unit dump truck jenis/tipe Hino dutro $130 \mathrm{HD}$ dengan kapasitas $10 \mathrm{~m}^{3}$. Total produktivitas untuk shovel didapat dari $32 \mathrm{~m}^{3}$ produktivitas/jam x 8 jam kerja/hari $=256 \mathrm{~m}^{3} /$ hari, Total produktivitas untuk excavator didapat dari $32,8 \mathrm{~m}^{3}$ produktivitas/jam x 8 jam kerja/hari $=262,4 \mathrm{~m}^{3} /$ hari dan total produktivitas dump truck didapat dari $5,16 \mathrm{~m}^{3}$ produktivitas/jam x 8 jam kerja/hari $=41,3 \mathrm{~m}^{3} /$ hari. Kombinasi keempat menghasilkan waktu 25 hari.

\section{DAFTAR PUSTAKA}

Asianto, 2008. Manajemen Alat Berat Untuk Konstruksi. Jakarta: PT Pradnya Paramita.

Brosur Excavator komatsu. (05 Maret 2018). Spesifikasi Excavator $\quad$ PC 200 (Online),(https://home.komatsu>worldwide.pdf, 2018).

Brosur Excavator CAT. (05 Maret 2018). Spesifikasi Excavator Long Arm PC 320. (Online), (https://ekatalog.scene7.com>produk>.pdf, 2018).

Brosur Dumptruck HINO. (05 Maret 2018). Spesifikasi HINO Dutro 130HD. (Online), (https://ekatalog.lkpp.go.id>produk> hino.pdf, 2018).

Brosur Dumptruck HINO. (05 Maret 2018). Spesifikasi Mitshubishi FUSO. (Online), (https://ktbfuso.co.id>donwloadbrochure.pdf, 2018).

Gafur, 2012. AnalisaPerhitungan Produktivitas Alat

Berat Pada Pelaksanaan Pematangan Lahan Untuk Pembuatan Work Shop Di Kab. Malinau Pada Dinas Pekerjaan Umum Provinsi
Kalimantan Timur Universitas 17 Agustus Samarinda Provinsi Kalimantan Timur. KURVA S Volume 1 Nomer 1 (2012) Universitas Sultan Ageng

Tirtayasa. Jurnal Sipil Statik, (Online), (http://ejurnal.untag.snd.ac.id/index.php/TEK/artic le/view/124,diakses 21 Maret 2018.

Nunnally, S. W. 2007. Construction Methods and Management, Seventh Edition. Prentice Hall, Inc. Jurnal Sipil Statik, (Online), (www.icivil-hu.com $>\quad$ civil-team>92578022-Construction-Methodsand-Management.pdf, diakses 05 April 2018)

Rochmanhadi, 1992. Alat berat dan Pengunaannya. Jakarta: Departemen Pekerjaan Umum.

Rostiyanti, Susy Fatena, 2008. Alat Berat Untuk Proyek Konstruksi, Jakarta: Penerbit Rineka Cipta, Hlm. 6.

Setiawati dkk., 2013. Analis Produktivitas Alat Berat Pada Proyek Pembangunan Pabrik Krakatau Posco Zone IV Di Cilegon Jurnal Konstruksia, Volume 4 Nomer 2 Juni 2013. Jurnal Sipil Statik, (Online), (download.portalgaruda.org > article > titleipi321516.pdf ,diakses 21 Maret 2018). Soeharto, Imam, 1997. Manajemen Proyek. Edisi kedua. Konsep, study kelayakan dan jaringan kerja Jakarta: Erlangga

Susanto dkk., 2015. Produktivitas Alat Berat Pada Pekerjaan Galian Gedung P1 P2 Uk Petra. Universitas Kristen Petra. Jurnal Sipil Statik, (Online), (publication.petra.ac.id > article > view, diakses 21 Maret 2018). 
Halaman Sengaja Dikosongkan 


\title{
Analisis Kinerja Operasional dan Kualitas Pelayanan PO. Mutiara Indah Murni dan PO. Widji Lestari pada Trayek Surabaya-Tuban
}

\author{
Amrita Winaya ${ }^{1}$, Theresia $\mathrm{MCA}^{2}$, Bimanda Maryudi $^{3}$ \\ 1,2,3 Jurusan Teknik Sipil, Fakultas Teknik Sipil dan Perencanaan, Institut Teknologi Adhi Tama, Surabaya \\ E-mail:amrita.winaya@itats.ac.id,longteyes@gmail.com
}

\begin{abstract}
ABSTRAK: Surabaya sebagai kota terbesar kedua di Indonesia dan sekaligus ibukota Provinsi Jawa Timur, menjadi magnet bagi para pendatang terutama yang berasal dari daerah-daerah di sekitarnya. Hal ini dapat meningkatkan pergerakan penduduk dari Kota Surabaya dan sebaliknya. Salah satunya adalah dari Surabaya menuju Tuban, kota-kota yang dilalui adalah Gresik, Lamongan, dan Bojonegoro. Untuk mengakomodasi pergerakan tersebut pemerintah selaku regulator bekerjasama dengan pihak swasta menyediakan sarana transportasi jalan raya berupa angkutan bus. Namun adakalanya terjadi kesenjangan jumlah penumpang antara satu perusahaan dengan perusahaan yang lain. Penelitian ini mengambil sampel dua buah perusahaan otobus (PO) yaitu PO. Mutiara Indah Murni dan PO. Widji Lestari. Instrumen yang digunakan pada pengumpulan data adalah kuesioner yang ditujukan bagi penumpang kedua PO tersebut. Untuk analisis menggunakan metode IPA atau Importance-Performance Analysis yang dapat mengukur tingkat kepentingan dan kinerja pelayanan. Dari hasil perhitungan dan analisis dapat diketahui bahwa faktor-faktor yang sangat berpengaruh terhadap pelayanan PO. Mutiara Indah Murni terdiri atas empat faktor yaitu keamanan, kenyamanan, waktu tempuh, dan kehandalan. Sedangkan faktor yang mempengaruhi kualitas pelayanan PO. Widji Lestari meliputi keamanan, kenyamanan, dan kehandalan. Dengan demikian PO. Widji Lestari lebih unggul dalam pelayanan apabila dibandingkan dengan PO. Mutiara Indah Murni yang masih memerlukan lebih banyak perbaikan dalam kualitas pelayanannya.
\end{abstract}

Kata Kunci : metode IPA, kualitas pelayanan, kinerja operasional bus

\section{PENDAHULUAN}

Sebagai kota terbesar kedua di Indonesia, Kota Surabaya memiliki jumlah penduduk yang cukup tinggi yaitu 2.765.000 jiwa berdasarkan data BPS tahun 2010. Dengan jumlah penduduk yang besar tersebut tentunya peluang pergerakan di dalam kota Surabaya maupun antara kota Surabaya dengan kota-kota-kota lainnya cukup tinggi. Salah satunya adalah pergerakan menuju Kota Tuban yang berjarak sekitar 103 kilometer dari Kota Surabaya. Dari Surabaya menuju Tuban melalui beberapa daerah yaitu Gresik, Lamongan, dan Bojonegoro, sehingga masyarakat yang menuju kota-kota tersebut dapat menggunakan moda transportasi dengan trayek Surabaya-Tuban.

Untuk mengakomodasi pergerakan tersebut, pemerintah selaku regulator dan fasilitator bekerjasama dengan pihak swasta dalam penyediaan sarana transportasi. Kerjasama ini salah satunya berupa Perusahaan Otobus (PO) yang menyediakan sarana angkutan jalan raya berupa bus, yang mana merupakan angkutan umum yang paling banyak digunakan oleh penumpang trayek Surabaya-Tuban.

Penggunaan jasa PO adakalanya tidak merata, dalam artian penumpang cenderung menggunakan PO yang sama sehingga PO yang lain menjadi sepi penumpang dan ada juga yang berhenti beroperasi. Oleh karena itu penulis melakukan penelitian mengenai kualitas pelayanan PO yang mempengaruhi pemerataan penumpang, yaitu pada PO. Mutiara Indah Murni dan PO. Widji Lestari. Kedua PO ini diambil sebagai sampel dan mempunyai titik keberangkatan yang sama yakni Terminal Osowilangun Surabaya dan titik kedatangan yang sama di Terminal Baru Tuban. Dari kedua PO ini akan dilakukan kajian mengenai kualitas pelayanan dan kinerja operasional menggunakan metode kuadran yaitu Importance Performance Analysis (IPA).

Tujuan dilakukannya penelitian ini meliputi dua hal yaitu mengidentifikasi variabel apa saja yang sangat mempengaruhi kualitas pelayanan masing-masing $\mathrm{PO}$, serta ingin mengetahui bagaimana kualitas pelayanan PO.
Mutiara Indah Murni dan PO. Widji Lestari terhadap penumpang bus, PO mana yang masih harus melakukan perbaikan terhadap kualitas pelayanannya.

\section{Metode Penelitian}

Sebelum pelaksanaan pengumpulan data, terlebih dahulu dilakukan tinjauan terhadap literatur yang bertujuan untuk memperoleh landasan teori dan dasar analisis yang terkait dengan penelitian. Beberapa diantaranya yaitu referensi mengenai perusahaan otobus, kualitas pelayanan angkutan umum, metode Importance Performance Analysis (IPA), serta kuesioner berupa skala likert.

Pada penelitian ini objek yang akan diteliti adalah Perusahaan Otobus atau disingkat PO, yang merupakan perusahaan penyedia angkutan darat untuk penumpang maupun barang berupa kendaraan bus (Nugroho, 2018).

Data primer yang diperlukan untuk penelitian ini meliputi jumlah penumpang PO. Mutiara Indah Murni dan PO. Widji Lestari, serta tingkat kepentingan dan kinerja pada aspek pelayanan masing-masing PO. Pengambilan sampel dilakukan dengan kuesioner menggunakan simple random sampling atau pengambilan sampel secara acak sederhana; sehingga setiap elemen populasi harus memiliki kesempatan yang sama untuk diambil sebagai sampel. Adapun pengambilan data jumlah penumpang dari masing-masing PO dilakukan selama satu minggu, sehingga berdasarkan teknik pengambilan sampel berupa Random Sampling dapat ditentukan jumlah sampel untuk PO. Mutiara Indah Murni adalah 23 orang, sedangkan jumlah sampel untuk PO. Widji Lestari adalah 33 orang.

Kuesioner merupakan instrumen atau alat pengukuran yang kemudian diuji validitas dan reliabilitasnya. Kuesioner tersebut dinyatakan valid apabila dapat mengukur suatu hal secara tepat seperti parameter yang hendak diukur (Rahmat, 2013). Sedangkan uji reliabilitas salah satunya dapat diukur menggunakan teknik Spearman Brown yang memiliki kriteria yaitu hanya tersedia dua pilihan jawaban untuk tiap pertanyaan, serta 
jumlah pertanyaan pada instrumen penelitian adalah genap (Siregar, 2017). Kuesioner yang diajukan kepada responden terdiri atas total 16 jumlah pertanyaan yang dikelompokkan menjadi delapan kategori atribut atau variabel pelayanan.

Menurut Rangkuti dalam Arifin (2015), salah satu alat analisis yang dapat digunakan untuk mengetahui kepuasan konsumen terhadap pelayanan jasa perusahaan adalah Importance-Performance Analysis (IPA). Pada metode ini dilakukan pengukuran tingkat kesesuaian untuk menentukan seberapa besar kepuasan pengguna jasa terhadap kinerja perusahaan, dan seberapa besar perusahaan sebagai penyedia jasa dapat memahami keinginan pelanggan (Nugraha dkk, 2014). Untuk melakukan analisis terhadap tingkat kepentingan dan kinerja suatu perusahaan, pada metode IPA dibuat matriks dua dimensi. Matriks ini membandingkan antara persepsi tingkat kepentingan konsumen yang mendorong penggunaan suatu produk atau pelayanan jasa (importance) dengan persepsi kepuasan konsumen terhadap kinerja produk atau jasa tersebut (performance). Perhitungan faktor-faktor kepentingan dan kinerja ini menggunakan nilai rata-rata dari hasil analisis kepentingan dan kinerja, sebagaimana dirumuskan pada formula di bawah ini:

$$
X=\frac{\sum_{i=1}^{n} X i}{n} \quad \text { dan } \quad Y=\frac{\sum_{i=1}^{n} Y i}{n}
$$

dengan:

$\mathrm{X}$ : nilai rata-rata tingkat kepuasan seluruh variabel

$\mathrm{Y}$ : nilai rata-rata tingkat kepentingan seluruh variabel

$\mathrm{X}_{\mathrm{i}}$ : nilai tingkat kepuasan variabel $\mathrm{i}$

$\mathrm{Y}_{\mathrm{i}}$ : nilai tingkat kepentingan variabel $\mathrm{i}$

$\mathrm{n}$ : jumlah responden

Kemudian selanjutnya adalah melakukan pengamatan atau observasi lapangan untuk menentukan waktu pelaksanaan survei. Dari observasi tersebut diperoleh waktu terpadat yaitu hari Sabtu pukul 10.00-14.00.

\section{Hasil dan Pembahasan}

Kuesioner yang telah disusun kemudian diuji validitasnya menggunakan rumus korelasi Product Moment, syaratnya adalah nilai $r$ hitung harus lebih besar daripada $\mathrm{r}$ tabel. Nilai $\mathrm{r}$ hitung dan $\mathrm{r}$ tabel adalah untuk masing-masing item pertanyaan. Apabila syarat tersebut telah dipenuhi, maka item pertanyaaan dinyatakan valid. Hasil dari perbandingan antara $r$ hitung dengan $r$ tabel ditunjukkan pada tabel 1 dan tabel 2, yang secara berurutan menggambarkan uji validitas kinerja dan uji validitas kepentingan PO. Mutiara Indah Murni.

Selain pengujian validitas, kuesioner juga perlu diuji reliabilitasnya, yang merupakan ketepatan atau akurasi dari alat ukur. Penilaian dilakukan dengan analisis statistik untuk mengetahui kesalahan ukur. Suatu instrumen atau alat ukur dikatakan reliabel jika instrumen tersebut cukup dipercaya untuk dijadikan sebagai alat ukur (Ong, 2014). Dalam uji reliabilitas ini dilakukan perhitungan menggunakan metode Spearman Brown. Hasil yang didapatkan yaitu dari 16 item pertanyaan kinerja dan kepentingan, yang diajukan ke responden PO. Mutiara Indah Murni maupun PO. Widji Lestari menunjukkan reliabilitasnya masuk kategori sangat tinggi. Kategori ini memiliki rentang nilai antara 0,800 sampai dengan 1,000 yang berarti item-item pertanyaan tersebut dinilai sangat konsisten pada hasilnya sehingga dapat dipergunakan secara berulangkali dalam periode waktu yang berbeda. Item pertanyaan masing-masing untuk kinerja dan kepentingan pelayanan sejumlah 16 tersebut dirangkum menjadi 8 kelompok variabel sebagaimana ditunjukkan pada tabel 1 dan tabel 2 berikut ini:

Tabel 1.Uji Validitas Kinerja PO.Mutiara Indah Murni

\begin{tabular}{lccc}
\hline $\begin{array}{l}\text { Variabel } \\
\text { Kinerja }\end{array}$ & r hitung & r tabel & Keterangan \\
\hline $\begin{array}{l}\text { 1.Kondisi fisik } \\
\text { kendaraan }\end{array}$ & 0,615 & 0,433 & Valid \\
\hline $\begin{array}{l}\text { 2. Ketersediaan } \\
\text { fasilitas tempat } \\
\text { duduk dan } \\
\text { kesesuaian } \\
\text { harga tiket }\end{array}$ & 0,538 & 0,433 & Valid \\
\hline $\begin{array}{l}\text { 3. Kebersihan } \\
\text { dalam } \\
\text { kendaraan }\end{array}$ & 0,489 & 0,433 & Valid \\
\hline $\begin{array}{l}\text { 4. Keamanan } \\
\text { dalam } \\
\text { kendaraan }\end{array}$ & 0,494 & 0,433 & Valid \\
\hline $\begin{array}{l}\text { 5. Pelayanan } \\
\text { petugas }\end{array}$ & 0,553 & 0,433 & Valid \\
\hline 6. Kenyamanan & 0,600 & 0,433 & Valid \\
\hline $\begin{array}{l}\text { 7. Waktu } \\
\text { Tempuh }\end{array}$ & 0,517 & 0,433 & Valid \\
\hline 8. Kehandalan & 0,555 & 0,433 & Valid \\
\hline
\end{tabular}

Tabel 1 merupakan variabel pelayanan untuk kinerja pada PO. Mutiara Indah, dari perbandingan $r$ tabel dengan $r$ hitung diperoleh hasil yang valid untuk semua item pertanyaannya. Nilai $r$ tabel untuk segi kepentingan maupun segi kinerja adalah sebesar 0,433. Setelah dilakukan perhitungan terhadap $r$ hitung untuk uji validitas kepentingan PO. Mutiara Indah, didapatkan hasil yang juga valid untuk keseluruhan pertanyaan pada variabelnya, yaitu dapat dilihat pada tabel 2 berikut ini:

Tabel 2. Uji Validitas Kepentingan PO.Mutiara Indah Murni

\begin{tabular}{lccc}
\hline $\begin{array}{l}\text { Variabel } \\
\text { Kepentingan }\end{array}$ & r hitung & r tabel & Keterangan \\
\hline $\begin{array}{l}\text { 1.Kondisi fisik } \\
\text { kendaraan }\end{array}$ & 0,548 & 0,433 & Valid \\
\hline $\begin{array}{l}\text { 2. Ketersediaan } \\
\text { fasilitas tempat } \\
\text { duduk dan } \\
\text { kesesuaian } \\
\text { harga tiket }\end{array}$ & 0,564 & 0,433 & Valid \\
\hline $\begin{array}{l}\text { 3. Kebersihan } \\
\text { dalam } \\
\text { kendaraan }\end{array}$ & 0,486 & 0,433 & Valid \\
\hline $\begin{array}{l}\text { 4.Keamanan } \\
\text { dalam } \\
\text { kendaraan }\end{array}$ & 0,524 & 0,433 & Valid \\
\hline $\begin{array}{l}\text { 5. Pelayanan } \\
\text { petugas }\end{array}$ & 0,516 & 0,433 & Valid \\
\hline
\end{tabular}




\begin{tabular}{lccc}
\hline $\begin{array}{l}\text { Variabel } \\
\text { Kepentingan }\end{array}$ & r hitung & r tabel & Keterangan \\
\hline 6. Kenyamanan & 0,527 & 0,433 & Valid \\
\hline $\begin{array}{l}\text { 7. Waktu } \\
\text { Tempuh }\end{array}$ & 0,495 & 0,433 & Valid \\
\hline 8. Kehandalan & 0,463 & 0,433 & Valid \\
\hline
\end{tabular}

Untuk uji validitas segi kinerja dan kepentingan PO. Widji Lestari ditampilkan pada tabel 3 dan tabel 4 di bawah ini:

Tabel 3. Uji Validitas Kinerja PO. Widji Lestari

\begin{tabular}{lccc}
\hline Variabel Kinerja & $\begin{array}{c}\mathbf{r} \\
\text { hitung }\end{array}$ & $\begin{array}{c}\mathbf{r} \\
\text { tabel }\end{array}$ & Keterangan \\
\hline $\begin{array}{l}\text { 1.Kondisi fisik } \\
\text { kendaraan }\end{array}$ & 0,566 & 0,355 & Valid \\
\hline $\begin{array}{l}\text { 2. Ketersediaan } \\
\text { fasilitas tempat duduk } \\
\text { dan kesesuaian harga } \\
\text { tiket }\end{array}$ & 0,458 & 0,355 & Valid \\
\hline $\begin{array}{l}\text { 3. Kebersihan dalam } \\
\text { kendaraan }\end{array}$ & 0,586 & 0,355 & Valid \\
\hline $\begin{array}{l}\text { 4. Keamanan dalam } \\
\text { kendaraan }\end{array}$ & 0,569 & 0,355 & Valid \\
\hline 5.Pelayanan petugas & 0,728 & 0,355 & Valid \\
\hline 6. Kenyamanan & 0,482 & 0,355 & Valid \\
\hline 7. Waktu Tempuh & 0,625 & 0,355 & Valid \\
\hline 8. Kehandalan & 0,569 & 0,355 & Valid \\
\hline
\end{tabular}

Dari hasil perhitungan nilai r untuk segi kinerja PO. Widji Lestari, dapat diketahui bahwa semua item pertanyaannya adalah valid, yang ditunjukkan dengan nilai $r$ hitung yang lebih besar daripada nilai $r$ tabel. Untuk segi kepentingan juga diperoleh nilai $r$ hitung yang lebih besar daripada nilai $r$ tabel, sehingga semua item pertanyaan pada segi kinerja dan kepentingan PO. Widji Lestari dinyatakan valid.

Tabel 4. Uji Validitas Kepentingan PO. Widji Lestari

\begin{tabular}{lccc}
\hline $\begin{array}{l}\text { Variabel } \\
\text { Kepentingan }\end{array}$ & $\begin{array}{c}\mathbf{r} \\
\text { hitung }\end{array}$ & $\begin{array}{c}\mathbf{r} \\
\text { tabel }\end{array}$ & Keterangan \\
\hline $\begin{array}{l}\text { 1.Kondisi fisik } \\
\text { kendaraan }\end{array}$ & 0,714 & 0,355 & Valid \\
\hline $\begin{array}{l}\text { 2. Ketersediaan } \\
\text { fasilitas tempat duduk } \\
\text { dan kesesuaian harga } \\
\text { tiket }\end{array}$ & 0,642 & 0,355 & Valid \\
\hline $\begin{array}{l}\text { 3. Kebersihan dalam } \\
\text { kendaraan }\end{array}$ & 0,700 & 0,355 & Valid \\
\hline $\begin{array}{l}\text { 4.Keamanan dalam } \\
\text { kendaraan }\end{array}$ & 0,639 & 0,355 & Valid \\
\hline 5.Pelayanan petugas & 0,794 & 0,355 & Valid \\
\hline 6. Kenyamanan & 0,534 & 0,355 & Valid \\
\hline 7. Waktu Tempuh & 0,679 & 0,355 & Valid \\
\hline 8. Kehandalan & 0,612 & 0,355 & Valid \\
\hline
\end{tabular}

Setelah dilakukan uji validitas dan uji reliabilitas kuesioner, analisis selanjutnya adalah pada penilaian masing-masing variabel aspek pelayanan dengan menggunakan metode IPA. Pada metode tersebut, responden diminta melakukan penilaian terhadap tingkat kepentingan dan kinerja untuk aspek pelayanan bus, yang digambarkan pada diagram kartesius dimana sumbu X menunjukkan kinerja sedangkan sumbu $\mathrm{Y}$ adalah kepentingan. Gambar 1 adalah hasil perhitungan dari aspek kinerja dan kepentingan pada PO. Mutiara Indah Murni.

Kuadran A yang terletak di kiri atas adalah prioritas utama (concentrate here), jika dilihat dari sisi kepentingan konsumen maka variabel pelayanan bus berada pada tingkat yang tinggi. Namun dari kepuasannya, konsumen

merasakan tingkat yang rendah sehingga menuntut perbaikan variabel pelayanan sebaik mungkin. Variabelvariabel yang termasuk dalam kuadran A ini meliputi tersedianya fasilitas keamanan, kenyamanan berupa fasilitas pendingin (AC) di dalam kendaraan, waktu tempuh, jadwal keberangkatan, dan jadwal kedatangan.

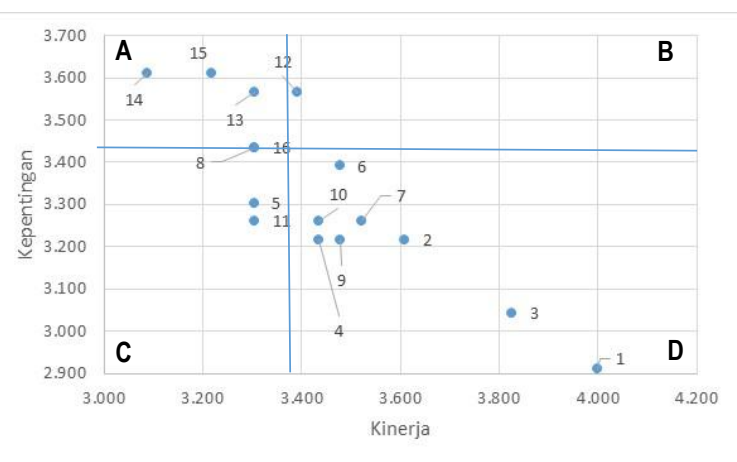

Gambar 1. Diagram Kartesius IPA untuk PO. Mutiara Indah Murni

Sedangkan kuadran B di kanan atas menggambarkan pertahankan prestasi (keep up the good work) yakni jika ditinjau dari segi kepentingan maupun kepuasan konsumen, variabel-variabel yang termasuk dalam kuadran ini berada pada tingkat yang tinggi. Dengan demikian, perusahaan dapat mempertahankan prestasinya yaitu tanpa diharuskan ada perbaikan kualitas karena variabel-variabelnya yang cukup menarik bagi konsumen, namun tetap dilakukan pengelolaan pelayanan dengan baik. Variabel-variabel dalam kuadran B ini yaitu kebersihan di dalam kendaraan dan tersedianya fasilitas kebersihan.

Untuk kuadran C yang berada di sisi kiri bawah merupakan prioritas rendah (low priority), dimana jika dilihat dari kepentingan konsumen maka variabel pelayanan dianggap tidak terlalu penting, dan dari kepuasan pelanggan juga tergolong kurang baik. Pada kuadran ini konsumen cenderung mengabaikan variabel pelayanan yang ada, akan tetapi lain halnya dengan PO. Mutiara Indah Murni yang sebaiknya perlu mewaspadai variabel pada kuadran ini karena tingkat kepentingan pengguna bus dapat berubah seiring dengan peningkatan kebutuhan. Variabel-variabel tersebut terdiri atas ketersediaan fasilitas, kebersihan, pelayanan petugas, dan kenyamanan tempat duduk di dalam kendaraan. 
Pada bagian kanan bawah terdapat kuadran D yaitu faktor-faktor yang dianggap tidak terlalu penting dan tidak diharapkan oleh pengguna jasa. Atau dengan kata lain, konsumen atau pengguna jasa sudah cukup puas dengan pelayanan yang disediakan, sehingga PO. Mutiara Indah Murni tidak perlu melakukan perbaikan pelayanan pada kuadran ini. Variabel-variabel pada kuadran ini mencakup kondisi fisik di dalam maupun di luar kendaraan, ketersediaan fasilitas tempat duduk yang mencukupi, tingka keamanan di dalam bus, dan pelayanan petugas yaitu kemampuan pengemudi dalam berkendara.

Untuk segi kepentingan dan kinerja pelayanan dari PO. Widji Lestari dapat dilihat pada Gambar 2. Hasil perhitungan aspek pelayanan untuk PO. Widji Lestari pada kuadran A menggambarkan bahwa pada variabel ketersediaan fasilitas keamanan, kenyamanan penumpang yang berupa berfungsinya fasilitas pendingin ruangan, serta kehandalan yang meliputi ketepatan jadwal keberangkatan dan kedatangan, konsumen merasakan tingkat kepuasan yang rendah. Akibatnya konsumen menuntut perbaikan pelayanan pada variabel-variabel tersebut. Oleh karena itu PO. Widji Lestari selaku operator dan penyedia layanan perlu melakukan perbaikan secara menyeluruh agar kepuasan pengguna jasa terhadap variabel-variabel pada kuadran ini dapat dipenuhi.

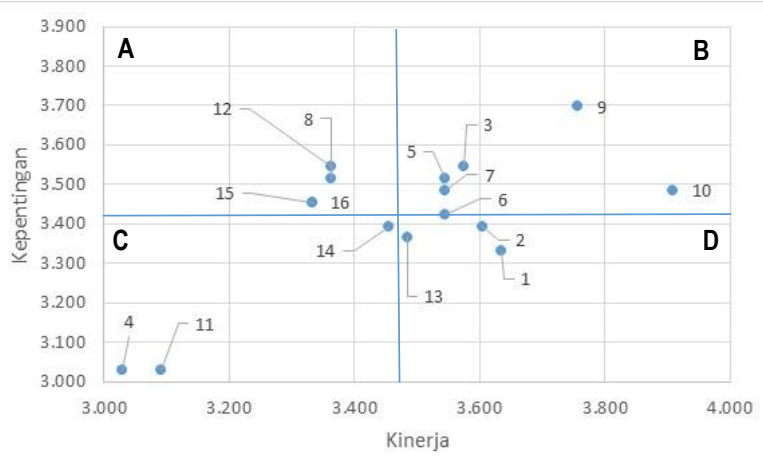

Gambar 2. Diagram Kartesius IPA untuk PO. Widji Lestari

Sementara itu pada kuadran B, perusahaan cukup mempertahankan kualitas pelayanannya dengan tetap mengusahakan pengelolaan jasa sebaik-baiknya. Variabel-variabel pelayanan pada kuadran ini tidak perlu diperbaiki, karena telah dapat menarik kepuasan konsumen. Aspek pelayanan yang termasuk dalam kuadran B ini yaitu ketersediaan fasilitas tempat duduk penumpang yang mencukupi, faktor kebersihan yakni kesadaran penumpang dan awak bus terkait kebersihan di dalam kendaraan dan tersedianya fasilitas kebersihan, tingkat keamanan bus, serta pelayanan petugas yang mencakup kemampuan pengemudi dan pelayanan kondektur yang ramah.

Pada posisi kuadran $\mathrm{C}$, aspek pelayanan yang masuk ke dalam kuadran ini adalah kesesuaian tarif dengan kualitas pelayanan, kenyamanan, dan waktu tempuh. Kenyamanan pada kuadran $\mathrm{C}$ ini adalah fasilitas tempat duduk yang nyaman. Jika dilihat dari kepuasan konsumen, variabel aspek pelayanan yang ada di kuadran ini dianggap tidak terlalu penting dan dari kepuasan pengguna juga kurang baik. Dengan demikian, PO. Widji
Lestari perlu mewaspadai variabel aspek pelayanan pada kuadran ini karena tingkat kepentingan konsumen dapat berubah seiring meningkatnya kebutuhan.

Untuk kuadran D dapat diketahui bahwa jika dilihat dari kepentingan pengguna jasa, variabel pelayanan yang ada di kuadran ini dianggap kurang penting, walaupun secara kepuasan konsumen sudah cukup tinggi. PO. Widji Lestari tidak perlu melakukan perbaikan karena untuk mencegah terjadinya pemborosan. Adapun variabelvariabel pelayanan yang termasuk dalam kuadran D ini terdiri atas kondisi fisik baik di dalam maupun di luar kendaraan, serta ketepatan waktu tempuh.

\section{Kesimpulan}

Berdasarkan hasil analisis data dapat diambil kesimpulan pada penelitian ini, yaitu terdapat beberapa variabel yang sangat berpengaruh terhadap pelayanan masing-masing PO. Untuk PO. Mutiara Indah Murni, variabel-variabel yang mempengaruhi kualitas pelayanan adalah keamanan, kenyamanan, waktu tempuh, dan kehandalan. Sedangkan untuk PO. Widji Lestari beberapa variabel yang berpengaruh terhadap kualitas pelayanan terdiri dari keamanan, kenyamanan, dan kehandalan. Variabel-variabel yang mempengaruhi kualitas pelayanan adalah yang termasuk dalam kuadran A, yaitu merupakan aspek pelayanan yang kurang baik dan mendapatkan prioritas utama dalam perbaikan kinerjanya.

Penilaian kualitas pelayanan yang diberikan oleh PO. Widji Lestari lebih baik daripada pelayanan oleh PO. Mutiara Indah Murni. Penumpang cenderung menggunakan jasa pelayanan bus dari PO. Widji Lestari dibandingkan dengan PO. Mutiara Indah Murni. Hal ini dapat diketahui dari variabel aspek pelayanan pada PO. Mutiara Indah Murni yang memerlukan lebih banyak perbaikan.

\section{Daftar Pustaka}

Arifin, Samsul Andy., Sulistyo, Harnen., Djakfar, Ludfi. (2015), Kajian Kepuasan Penumpang Terhadap Kinerja Pelayanan Maskapai Penerbangan Rute Surabaya-Jakarta (Studi Kasus: Bandar Udara Internasional Juanda Surabaya), Jurnal Tata Kota dan Daerah, Volume 7 No.1.

Nugraha, Rizal., Harsono, Ambar., Adianto, Hari. (2014), Usulan Peningkatan Kualitas Pelayanan Jasa pada Bengkel " $X$ " Berdasarkan Hasil Matrix ImportancePerformance Analysis (Studi Kasus di Bengkel AHASS PD.Sumber Motor Karawang), Reka Integra Jurnal Online Institut Teknologi Nasional.

Nugroho, Bimanda Maryudi. (2018). Analisis Kualitas Pelayanan PO. Mutiara Indah Murni dan PO. Widji Lestari Terhadap Daya Pilih Responden Pada Trayek Surabaya-Tuban Dengan Titik Keberangkatan Terminal Osowilangun dan Titik Kedatangan Terminal Baru Tuban, Skripsi Tidak Diterbitkan, Institut Teknologi Adhi Tama, Surabaya.

Ong, Johan Oscar., Pambudi, Jati. (2014), Analisis Kepuasan Pelanggan dengan Importance Performance Analysis di SBU Laboratory Cibitung PT.Sucofindo (Persero), Jati Undip Vol.IX No.1.

Rahmat, Dr.H.Msi. (2013), Statistika Penelitian, CV.Pustaka Setia, Bandung. 
Siregar, Sofyan. (2017), Statistik Parametrik Untuk Penelitian Kuantitatif, Dilengkapi dengan Perhitungan Manual dan Aplikasi SPSS Versi 2017, Bumi Aksara, Jakarta. 
Jurnal Rekayasa Tenik Sipil Universitas Madura Vol. 4 No.2 Desember 2018 ISSN 2527-5542

Halaman Sengaja Dikosongkan 


\title{
ANALISIS PERCEPATAN DURASI TERHADAP PEKERJAAN PROYEK KONSTRUKSI TIME COST TRADE OFF METHOD ( STUDI KASUS : PEMBANGUNAN GEDUNG DINAS PERDAGANGAN DAN PERINDUSTRIAN KABUPATEN SAMPANG )
}

\author{
Dedy Asmaroni ${ }^{1}$ and Ach Fendi ${ }^{2}$ \\ ${ }^{1}$ Teknik Sipil, Fakultas Teknik, Universitas Madura, Pamekasan \\ ${ }^{2}$ Teknik Sipil, Fakultas Teknik, Universitas Madura, Pamekasan \\ E-mail: dedyasmaroni@gmail.com,Ferefendy319@yahoo.com.
}

\begin{abstract}
ABSTRAK: Dalam pembangunan gedung dimana suatu konstruksi pekerjaan suatu proyek terdapat berbagai hal yang terjadi seperti, bertambahnya waktu dan kerusakan alat sehingga pelaksanaan akan mengakibatkan keterlambatan sehingga membutuhkan suatu perencanaan, penjadwalan serta pengendalian yang baik. Perencanaan dan penjadwalan yang kurang baik akan berdampak pada pekerjaan dan pelaksanaan konstruksi. Oleh karena itu, bisa dilakukan percepatan proyek konstruksi agar permasalahan yang ada bisa teratasi sesuai proses diharapkan. Metode yang digunakan pada penelitian ini merupaka metode deskriptif dengan jenis penelitian studi kasus. Penelitian studi kasus adalah penelitian suatu kasus studi atau subyek, tujuan dari studi kasus ini memberikan gambaran secara detail mengenai latar belakang dan sifat serta karakteristik khas dari suatu kasus studi sehingga dapat memahami objek yang ditelitinya. Hasil penelitian yang telah dilakukan menunjukkan dari hasil penjadwalan ulang pembangunan gedung kantor Dinas Perdagangan dan Perindustrian dengan menerapkan metode TCTO (Time Cost Trade Off) didapat waktu penyelesaian akibat percepatan adalah 133 hari dari durasi penyelesaian sebesar 150 hari jadi diperlukan percepatan 17 hari agar proyek dapat selesai sesuai target rencana. Adapun biaya total akibat dilakukan percepatan sebesar Rp. 1.256.929.349 dari biaya sebelumnya Rp. 1.227.823.795 terjadi penambahan biaya sebesar Rp. 29.105.553 sehingga didapat $2,37 \%$ kenaikan anggaran.
\end{abstract}

Kata kunci: Percepatan Durasi, Pekerjaan Proyek Konstruksi, Time Cost Trade Off.

\section{Pendahuluan}

Dengan seiringnya perkembangan ilmu pengetahuan diera globalisai dan kemajuan zaman, baik dari segi teknologi maupun perkembangan tentu akan di sertai peningkatan kebutuhan manusia dalam berbagai aspek kehidupan dimana adanya perkemabangan akan ada pertambahan kebutuhan serta bertambahnya pendudukdi kawasan Kabupaten Sampang, dimana itu berdampak pada perdagangandan perindustrian sehingga mengalami kesulitan dimana kebutuhan semakin meningkat. Peningkatan pada perdagangan dan perindustrian tersebut menyebabkan kesulitan dalam hal melayani dengan peralatan yang kurang memadai oleh karena itu adanya peralatan dan tempat serta alat untuk memenuhi kebutuhan masyarakat. Maka dari itu peningkatan dalam pelaksanaan pelayanan sangat penting bagi kebutuhan masyarakat agar bisa terpenuhi. .

Suatu pembagunan gedung konstruksi untuk menyediakan tempat yang lebih baik untuk masyarakat. Dalam pembangunan gedung dimana suatu konstruksi pekerjaan suatu proyek terdapat berbagai hal yang terjadi seperti, bertambahnya waktu dan kerusakan alat sehingga pelaksanaan akan mengakibatkan keterlambatan oleh karena itu membutuhkan suatu perencanaan, penjadwalan serta pengendalian yang baik. Perencanaan dan penjadwalan yang kurang baik akan berdampak pada pekerjaan dan pelaksanaan kontruksi. Hal tersebut dipengaruhi oleh kualitas dan ketersedianbahan material, serta lokasi pembangunan proyek.

Seperti pada proyek pembangunan gedung Dinas Perdagangan dan Perindustrian Kabupaten Sampang, dimana pada proyek tersebut tempat yang biasa digunakan untuk meletakkan material kontruksi sekarang digunakan untuk tempat parkir kendaraan para pegawai karena sepeda motor hingga menduduki bahu jalan karena karena keterbatasan lahan. Para pegawai juga merasa kesulitan dalam bekerja karena kekurangan tempat dan peralatan dalam jangka waktu pembangunan gedung Dinas Perdagangan dan Perindustrian Kabupaten Sampang dimana masyarakat mengalami antrian dan lamanya proses.

Oleh karena itu bisa dilakukan percepatan proyek kontruksi agar permasalahn yang ada bisa teratasi sesuai proses diharapkan. Hal ini yang akan di amati untuk memenuhi penelitian skripsi yang berjudul "Analisis Percepatan Durasi Terhadap Pekerjaan Proyek Konstruksi Time Cost Trade Off Methodestudi kasus Pembangunan Gedung Dinas Perdagangan dan Perindustrian Kabupaten Sampang" agar didapat durasi waktu yang optimal dan tepat.

\section{Lokasi Penelitian}

Kantor Dinas Perdagangan dan Perisdustrian Kabupaten Sampang. Studi kasus pada penelitian kali ini dilakukan pada proyek pembangunan kontruksi Dinas Perdagangan dan Perindustrian Kabupaten Sampang yang berlokasi di Jln.Diponegoro No.52A kecamatan sampang kabupaten sampang 2017. Dapat di lihat pada Gambar 1 peta dibawah ini. 


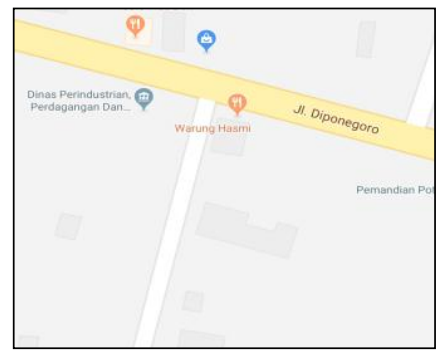

Gambar.1. Peta Lokasi Pembangunan Gedung Proyek

\section{Metode penelitian}

Metode yang digunakan pada penelitian ini merupakan metode diskriptif dengan jenis penelitian studi kasus. Penelitian studi kasus adalahpenelitian suatu kasus studi atau subyek, tujuan dari studi kasus ini memberikan gambaran secara detail mengenai latar belakang dan sifat serta karakteristik khas dari suatu kasus studi sehingga dapat memahami objek yang ditelitinya.

\section{Jenis Data}

Ada dua jenis data yang dapat di gunakan dalam penelitian ini yaitu :

\section{1) Data Primer}

Data primer adalah data yang diperoleh langsung dari subyek maupun sumber asli, data primer ini berupa data wawancara dengan pihak-pihak yang terkait dalam pelaksanaan proyek kontruksi mengenai biaya dan komponen serta yang lainnya.

a. Kurva $S$

Kurva $S$ merupakan data yang digunkan sebagai data variabel waktu penyelesaian proyek. Kurva $\mathrm{S}$ diperlukan untuk menegetahui waktu dan durasi terhadap masing-masing pekerjaan, selain itu juga dapat digunakan sebagai acuan durasi waktu normal proyek.

b. Rencana Anggaran Biaya ( RAB )

Rencana anggaran biaya ( RAB ) merupakan data-data pekerjaan serta biaya yang dibutuhkan sebagai variabel sebagai acuan biaya nomal.

c. Daftar harga satuan upah yang digunakan oleh konsultan perencana adalah harga pemerintah.

\subsubsection{Data skunder}

Data sekunder adalah data yang diperoleh dari pihak lain atau secara tidak langsung, dan data yang sudah tersedia sehingga hanya perlu dicari, dikumpulkan dan diolah yang diperoleh dari intansi terkait.

a. Laporan Mingguan

Laporan harian ialah laporan yang dibuat oleh pelaksana lapangan untuk mengetahui ke adaan dan kondisi manajemen proyek.

b. Laporan Bulanan

Laporan yang dibuat oleh pelaksana lapangan dari laporan mingguan untuk dijadikan laporan bulanan.

\subsection{Prosedur Penelitian}

Prosedur penelitian adalah suatu penelitian harus dilakukan sistematis dengan urutan yang jelas dan teretur, sehingga akan di peroleh suatu hasil dengan yang di harapkan. Oleh sebab itu, pelaksanaan penelitian ini dibagi dalam beberapa tahap-tahap sebagai berikut :

\section{Tahap I : Pesiapan Pendahuluan}

Pada tahap Persiapan ini merupakan pendahuluan sebelum melakukan suatu penelitian adapun persiapan-persiapan alat serta yang lainnya.

Tahap II : penentuan obyek penelitian

Diman pada tahap ini adalah untuk menentuakan lokasi letak proyek yang akan dilakukan penelitian sehingga dapat mengetahui lokasi proyek tersebut.

Tahap III : pengumpulan data

Merupakan langkah-langkah yang dilakukan, mengumpulkan data sekunder maupun primer yang akan dijadikan sebagai obyek penelitian dari konsultan perencana data-data meliputi sebagai berikut :

1. Rencana anggaran biaya ( RAB ).

2. Analisis harga satuan pekerjaan.

3. Kurva $\mathrm{S}$.

4. Daftar harga satuan upah

Tahap IV : Analisis data

Menganalisis data normal duration dan normal cost keduanya diperoleh dari pengumpulan data. Pelaksanaan suatu percepatan durasi dilakukan pada kondisi normal dan percepatan untuk menghindari denda dengan menggunakan penambahan jam kerja lembur.

Dari uraian di atas dapat ditulis sebagai berikut ini:

1. Produktivitas harian $=$ Volume durasi normal

2. Produktivitas tiap jam $=$ Produktivitas harian jam kerja perhari.

3. Produktivitas harian sesudah $c r a s h=($ Jam kerja perhari $\times$ Produktivitas tiap jam $)+(\mathrm{a} \times \mathrm{b} \times$ Produktivitas tiap jam ).

Dengan: $\mathrm{a}=$ lama penambahan jam kerja (lembur).

$\mathrm{b}=$ koefisien penurunan produktivitas akibat penambahan jam kerja (lembur ).

Dari uraian di atas dapat ditulis sebagai berikut ini:

1. Produktivitas harian $=$ Volume durasi normal .

2. Produktivitas tiap jam $=$ Produktivitas harian jam kerja perhari.

3. Produktivitas harian sesudah crash $=(\mathrm{Jam}$ kerja perhari $\times$ Produktivitas tiap jam $)+(a$ $\times \mathrm{b} \times$ Produktivita tiap jam).

Dengan: $\mathrm{a}=$ lama penambahan jam kerja (lembur)

$\mathrm{b}=$ koefisien penurunan produktivitas akibat penambahan jam kerja (lembur).

4. Crash duration $=$ Volume produktivitas harian sesudah Crash

Tabel2.2. Nilai koefisien penurunan produktivitas

\begin{tabular}{|c|c|c|}
\hline Jam lembur & $\begin{array}{c}\text { Penurunan } \\
\text { Indeks } \\
\text { produktivitas }\end{array}$ & $\begin{array}{c}\text { Prestasi } \\
\text { Kerja }\end{array}$ \\
\hline 1 jam & 0.1 & 90 \\
\hline 2 jam & 0.2 & 80 \\
\hline 3 jam & 0.3 & 70 \\
\hline 4 jam & 0.4 & 60 \\
\hline
\end{tabular}

Perhitungan untuk penambahan tenaga kerja dirumuskan sebagai berikut ini :

1. Jumlah tenaga kerja normal $=($ Koefisien tenaga kerja $x$ Volume $)$..........Pers. 1 
Durasi waktu

2. Jumlah tenaga kerja dipercepat

$=($ Koefesien tenaga kerja $\times$ volume $)$........Pers. 2

Durasi dipercepat

Dari rumus di atas maka akan diketahui jumlah pekerja normal dan jumlah penambahan tenaga kerja akibat percepatan durasi proyek.

Perhitungan untuk biaya tambahan pekerja dapat dirumuskan sebagai berikut ini:

3. Normal ongkos pekerja perhari

$=$ Produktivitas harian $\times$ Harga satuan upah pekerja......................................Pers. 3

4. Normal ongkos pekerja perjam

$=$ Produktivitas perjam $\times$ Harga satuan upah pekerja...................................................Pers. 4

5. Biaya lembur pekerja

$=1,5 \times$ upah sejam normal untuk penambahan jam kerja (lembur) pertama $+2 \times n \times$ upah sejam normal untuk penambahan jam kerja

(lembur) berikutnya... Pers. 5

Dengan: $\mathrm{n}=$ jumlah penambahan jam kerja (lembur)

6.Crash Cost pekerja perhari

$=($ Jam kerja perhari $\times$ Normal cost pekerja $)+$

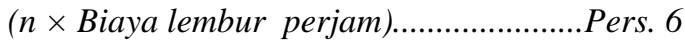

7. Costslope

$=\underline{\text { Cras Cost }- \text { Normal Cost }}$

..Pers. 7

Durasi Normal - Durasi Cras

4. Crash duration $=$ Volume produktivitas harian sesudah Crash

Tahap V : pembahasan

Dari data-data yang sudah diolah agar menghasilakan data yang di butuhkan dalam penelitian yang akan dibahas untuk menentukan perbandingan biaya awal sampai percepatan dilakukan.

Tahap VI : Kesimpulan dan Saran

Rangkuman dari permasalahan yang terjadi pada pembangunan yang suadah dilakukan percepatan dan menghasilkan perbandingan biaya-biaya yang terjadi.

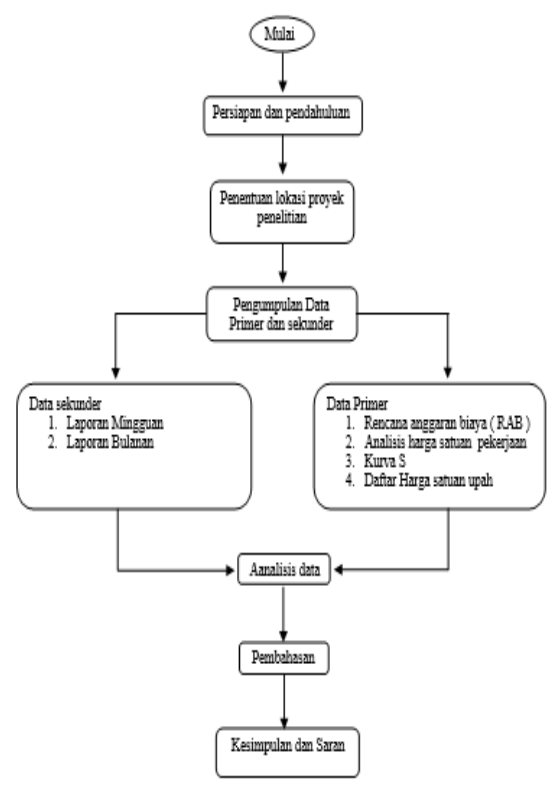

ANALISA DAN PEMBAHASAN

\section{Menyusun Analisa}

1) Identifikasi aktivitas (kegiatan)

Identifikasi aktivitas (kegiatan) sisa dilakukan hanya sampai pekerjaan struktur selesai, yaitu sampai pengerjaan lantai atap. Identifikasi ini kita tinjau mulai minggu ke 1 hingga minggu ke 20 prestasi struktur yang harus dicapai $100 \%$.

\section{2) Perhitunan produktivitas harian normal}

Setelah aktivitas (kegiatan) sisa proyek didapatkan, maka langkah selanjutnya menentukan hubungan keterkaitan antar aktivitas (predecessor dan successor) berdasarkan urutan pekerjaan dilapangan. Hubungan antar aktivitas ini disesuaikan dengan kapan aktivitas ini harus dimulai dan kapan harus selesai. Hubungan antar aktivitas diperoleh dari jadwal yang terdapat dilapangan, yang kemudian dibreakdown menjadi sub-sub pekerjaan.

\section{3) Hubungan keterkaitan antar aktivitas ( kegiatan )}

Setelah durasi proyek didapatkan, maka langkah selanjutnya menentukan hubungan keterkaitan antar aktivitas (predecessor dan successor) berdasarkan urutan pekerjaan dilapangan. Hubungan antar aktivitas (kegiatan) ini disesuaikan dengan kapan aktivitas (kegiatan) ini harus dimulai dan kapan harus selesai.

\section{Analisa Time Cost Trade Off \\ 1) Membuat Network diagram dan menghitung normal Duration}

Setelah mengetahui hubungan antar aktivitas (kegiata) (predecessor dan successor) dan kita telah menghitung durasi dari masing-masing aktivitas (kegiatan) berdasarkan produktivitas normal, maka langkah selanjutnya adalah membuat jaringan kerja (network planning).

Dalam menyusun hubungan antar aktivitas (kegiatan) maupun kapan suatu aktivitas (kegiatan) dilapangan dimulai dan kapan harus selesai. Setelah itu untuk menyusunnya kami menggunakan bantuan program Microsoft Project.

Kemudian dari jaringan kerja yang telah selesai dapat kita lihat normal duration, yaitu total durasi yang dibutuhkan untuk menyelesaikan aktivitas sisa yang ada.

\section{2) Menghitung Normal Cost}

Produktivitas harian percepatan diperoleh dari jumlah produktivitas harian normal dengan produktivitas pekerjaan saat jam lembur per hari. Penambahan jam kerja lembur sesuai peraturan yang berlaku dilakukan selama 3 jam per hari, sedangkan produktivitas pekerja jam lembur diasumsikan mengalami penurunan, dan hanya diperhitungkan sebesar $80 \%$ dari produktivitas jam kerja regular.

percepatan pekerjaan kritis adalah sebagai berikut :
a. Menghitung volume pekerjaan
b. Menghitung durasi normal
c. Menghitung produktivitas harian normal
d. Produktivitas normal/jam
e. Produktivitas jam lembur
f. Produktivitas harian percepatan 
Perhitungan produktivitas harian normal pada Pengukuran \& Bowplank:
a. Volume pekerjaan
$=86,1 \mathrm{~m}$
$\begin{array}{ll}\text { b. } \text { Harga Satuan } & =\text { Rp. } 63.790,96 / \mathrm{m} \text { ' } \\ \text { c. } \text { Normal cost } & =\text { Rp 5.492.401,656 } \\ \text { d. } \text { Durasi normal } & =8 \text { hari }\end{array}$
e. Produktivitas harian normal $=\mathrm{a} / \mathrm{d}$

$=\frac{86.1 \mathrm{~m} t}{8 \text { hari }}=10.763 \mathrm{~m}$ ' /hari

f. Produktivitas normal/jam $=\mathrm{e} / 8$

$=\frac{10.763 \mathrm{~m}^{J} / \text { hari }}{8 \mathrm{jam} / \mathrm{hari}}=1,345 \mathrm{~m}^{\prime} / \mathrm{jam}$

g. Produktivitas Lembur $/ \mathrm{Jam}=3 \times \mathrm{f}$ x 0,80 $=3 \times 1,345 \times 0,80$ $=3,229 \mathrm{~m} / \mathrm{jam}$

h. Produktivitas harian percepatan $=(\mathrm{f}+\mathrm{g}) \times 8$ $=(1,345+3,229) \times 8$ $=36,593 \mathrm{~m}$ ' / hari

Dengan cara yang sama perhitungan produktivitas harian, normal dan percepatan di gambarkan pada tabel 4.1 .

Tabel 4.1. Produktivitas harian percepatan

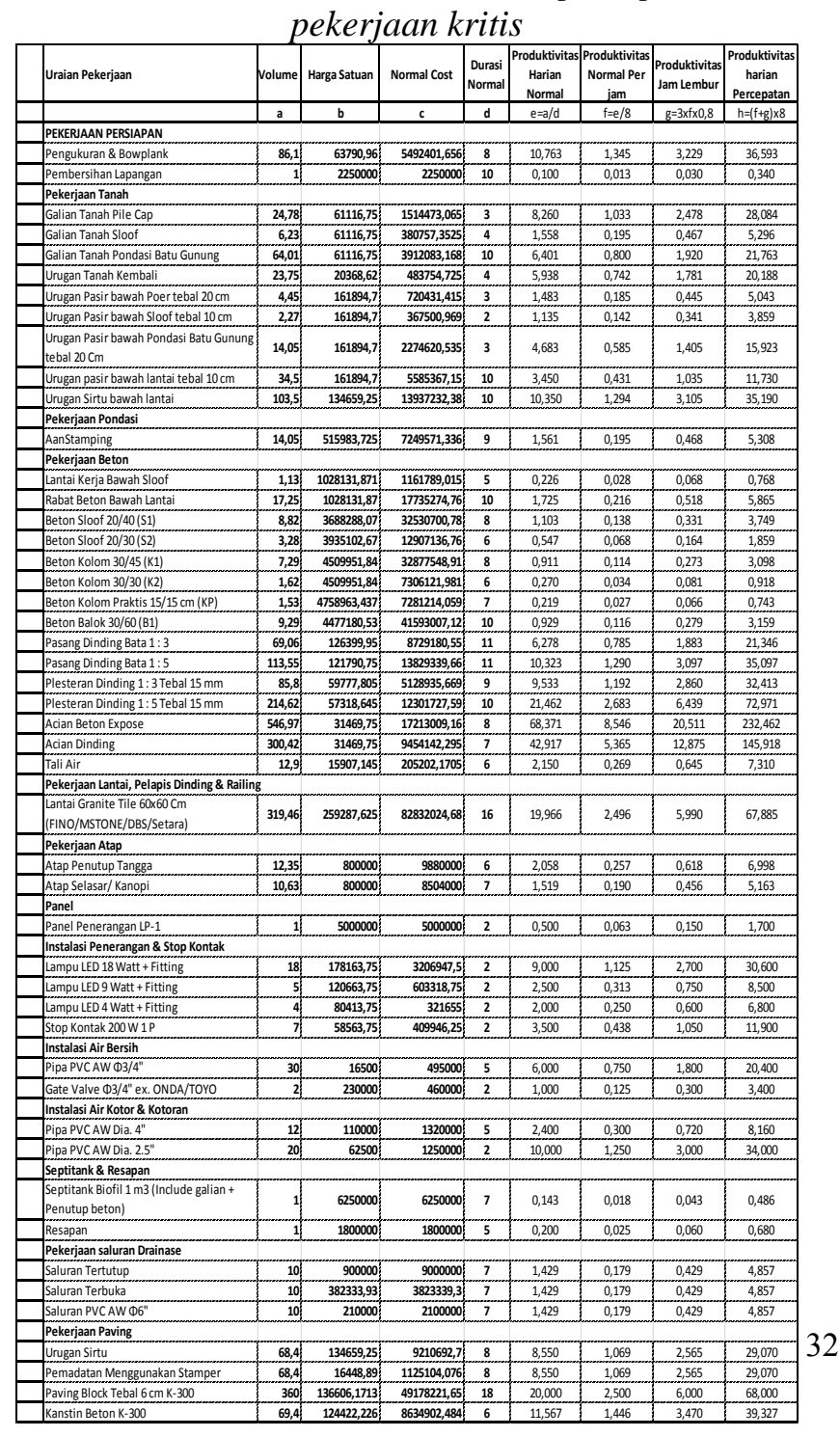

\subsection{Perhitungan Crash Duration, Crash Cost, danCost Slope}

Setelah diketahui besarnya produktivitas (kegiatan) harian percepatan pekerjaan kritis, maka langkah selanjutnya adalah menghitung durasi percepatan (crash duration) dan biaya langsung percepatan (crash cost). Perhitungan crash duration ini digunakan untuk mendapatkan batasan waktumaksimal suatu aktivitas

mampu untuk dilakukan crashing (crashability), sedangkan perhitungan crash cost digunakan untuk mencari slope biaya (cost slope) masing-masing aktivitas (kegiatan).

Untuk menentukan Crash Cost dapat dilakukan dengan langkah-langkah berikut:

a. Menghitung upah kerja harian normal, yaitu produktivitas harian $\mathrm{x}$ harga satuan upah kerja

b. Menghitung upah kerja normal, yaitu produktivitas per jam x harga satuan upah kerja

c. Menghitung upah kerja lembur per hari:

1. Untuk 3 jam lembur $=(1,5 \mathrm{x}$ upah jam normal $)+2(2 x$ upah jam normal $)$

2. Untuk 4 jam lembur $=(1,5 \mathrm{x}$ upah jam normal $)+3(2 \times$ upah jam normal $)$

d. Menghitung Crash Cost per hari, yaitu upahharian + upah kerja lembur per hari

e. Menghitung Crash Cost total, yaitu CrashCost per hari + Crash Duration

Perhitungan crash duration, crash cost, dan cost slope untuk Pekerjaan Lapis Permukaan Agregat sebagai berikut:

a. Volume pekerjaan $=86,1 \mathrm{~m}$

b. Durasi Normal $=8$ Hari

c. Normal cost $=$ Rp 5.492.401,656

d. Harga satuan = Rp. 63.790,96/m

e. Produktivitas normal $/$ hari $=10,763 \mathrm{~m} / \mathrm{jam}$

f. Produktivitas normal $/ \mathrm{jam}=1,345 \mathrm{~m} / \mathrm{jam}$

g. Produktivitas Lembur $/ \mathrm{Jam}=3,229 \mathrm{~m} / \mathrm{jam}$

h. Produktivitas harian percepatan $=36,593 \mathrm{~m} / \mathrm{hari}$

i. Crash duration

$$
\begin{aligned}
& =\mathrm{b}-\frac{\mathrm{a}}{\mathrm{h}} / 8 \\
& =8-\left(\frac{86.1 \mathrm{~m}^{\prime}}{836,593 \mathrm{~m}^{\prime} / \text { hari }} / 8\right)=7 \text { hari }
\end{aligned}
$$

j. Upah normal/jam $=\mathrm{d} \times \mathrm{f}$

$$
\begin{aligned}
\mathrm{k} . \text { Upah normal/hari } & =\mathrm{j} \times 8 \\
& =\operatorname{Rp} 85.818,78 / \mathrm{jam} \times 8 \\
& =\operatorname{Rp} 686.550,207 / \text { hari }
\end{aligned}
$$$$
=\operatorname{Rp} 63.790,96 / \mathrm{m} \times 1,345
$$$$
\mathrm{m} / \mathrm{jam}
$$$$
=\operatorname{Rp} 85.818,78 / \mathrm{jam}
$$

1. Upah 3 jam lembur/ hari $=(1,5 \times \mathrm{j})+2 \times(2 \times \mathrm{j})$

$=(1,5 \times \operatorname{Rp} 85.818,78)+2 \times(2 \times \operatorname{Rp} 85.818,78)$

$=\operatorname{Rp} 472.003,267 /$ hari

m. Cost Upah Percepatan/hari $=(\mathrm{c}+1) / \mathrm{i}$

$=($ Rp. 5.492.401,656 + Rp. 472.003,267) $/ 7$

$=$ Rp.852.057,846/hari

n. Cost upah $=(\mathrm{c}+\mathrm{m})$

$$
=\mathrm{Rp} 5.492 .401,656 / \text { hari }+\mathrm{Rp}
$$


Jurnal Rekayasa Tenik Sipil Universitas Madura Vol. 4 No.2 Desember 2019 ISSN 2527-5542

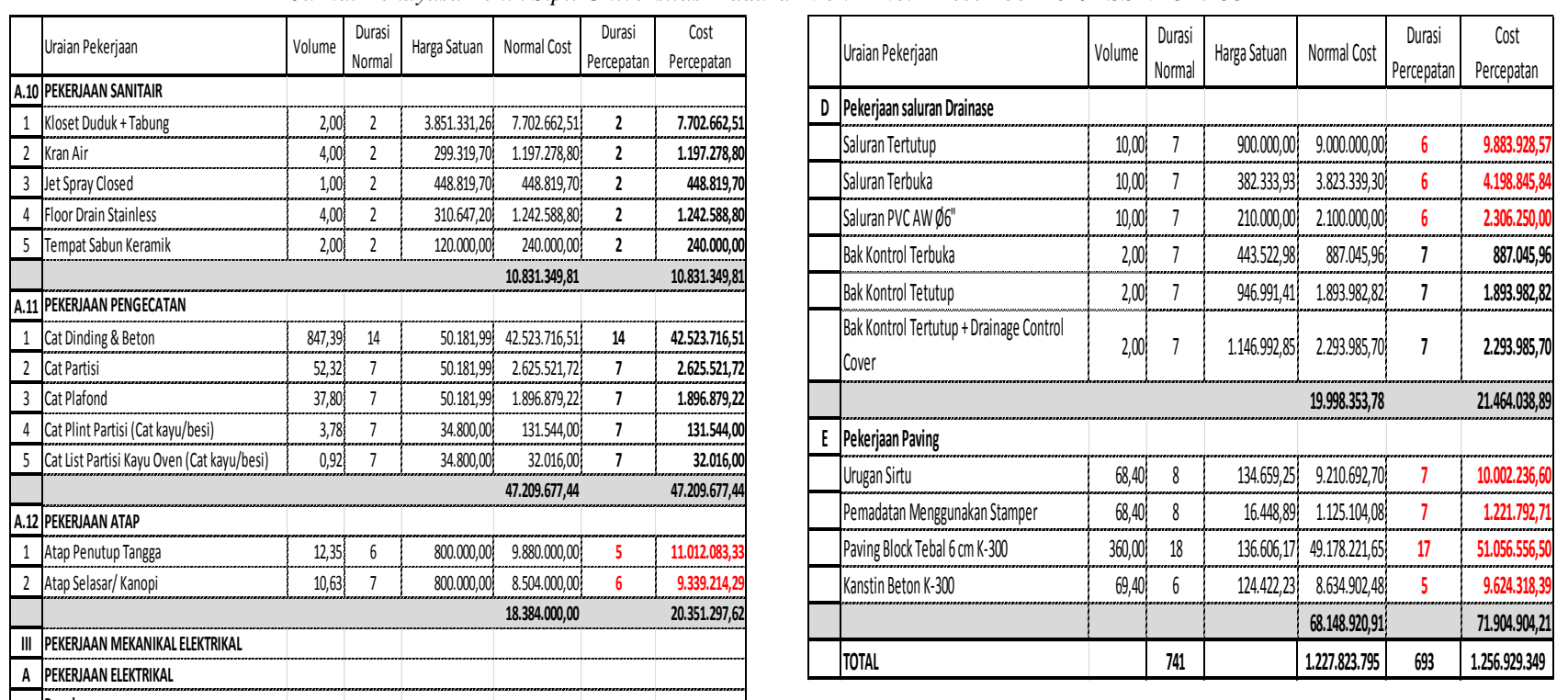

Sumber : ( Microsoft Project)

Dari Tabel 4.2. diatas didapat 48 pekerjaan proyek yang dipercepat diperoleh :

a. Hasil Kalkulasi Seluruh Pekerjaan( Microsoft Project ):

1. Durasi penyelesaian : 150 hari

Total biaya penyelesaian : Rp. 1.227.823.795

2. Durasi setelah dipercepat : 133 hari

Total biaya percepatan : Rp. 1.256.929.349

3. Durasi percepatan : Durasi penyelesaian - Durasi percepatan

$$
: 150-133
$$

: 17 hari

4. Biaya percepatan : Biaya percepatan - Biaya penyelesaian

$$
\text { :Rp. 1.256.929.349 - Rp. 1.227.823.795 }
$$

: Rp. 29.105 .553

$$
\begin{aligned}
& =\text { Rp. } 29.105 .553=\operatorname{Rp} 1.227 .823 .795 \times \frac{\mathrm{x}}{100} \\
\mathrm{X} & =\frac{\operatorname{Rp} 29.105 .553}{\operatorname{Rp} 1.227 .823 .795} \\
& =2.37 \%
\end{aligned}
$$

5. Biaya tak langsung waktu penyelesaian : 5\% x Biaya penyelesaian

:5\% x Rp. 1.227 .823 .795

: Rp. 61.391.189,76

6. Biaya tak langsung waktu penyelesain perhari :

: Biaya tak langsung waktu penyelesaian

$$
\text { : } \frac{61.391 .189,76}{741}
$$

: Rp.82.849.109

7. Biaya tak langsung waktu dipercepat yang dipercepat

: $5 \%$ x Biaya total proyek

: $5 \%$ x Rp. 1.256.929.349

: Rp. 62.846.467,4

8. Biaya tak langsung waktu dipercepat perhari :

$$
\begin{aligned}
& : \frac{\text { Biaya tak langsung waktu penyelesaian }}{\text { Durasi Penyelesaian }} \\
& : \frac{62.846 .467,76}{693}
\end{aligned}
$$

: Rp 90.687.543,7 


\section{KESIMPULAN}

Berdasarkan hasil analisa yang telah dilakukan dalam Tugas Akhir ini, dihasilkan kesimpulan yaitu sebagai berikut:

1. Dari hasil penjadwalan ulang pembangunan Gedung Kantor Dinas Perdagangan dan Perindustrian dengan menerapkan metode ( Time Cost Trade Off ) didapat waktu penyelesaian akibat percepatan adalah 133 hari dari durasi penyelesaian sebesar 150 hari jadi diperlukan percepatan 17 hari agar proyek dapat selesai sesuai target rencana.

2. Biaya total akibat pecepatan sebesar Rp. 1.256.929.349 dari biaya sebelumnya Rp. 1.227.823.795 terjadi penambahan biaya sebesar Rp. 29.105.553 Sehinnga didapat $2.37 \%$ kenaikan anggran.

\section{SARAN}

1. Diharapkan untuk peneliti selanjutnya dapat mengembangkan penelitian tentang Analisa Time Cost Trade Off, misalnya dengan mengembangkan analisa dengan menambahkan pekerjaan arsitektur.

2. Perhitungan yang dilakukan akan lebih bermanfaat apabila dipakai kontraktor menengah kebawah yang menangani beberapa proyek lebih dari dua proyek.

\section{DAFTAR PUSTAKA}

Febriyannor, R. 2016. Analisis Percepatan Pelaksanaan Pembagunan Rusunawa Dengan menambah Jam Kerja dan Tenaga Kerja Menggunakan Tracking MS. Project. Skripsi. Program Pascasarjana Universitas Brawijaya. Malang

Kisworo, R.W. et al. 2017. Analisis Percepatan Proyek Menggunakan Metode Time Cost Trade Off Dengan Penambahan Jam Kerja Lembur dan Jumlah Alat. E-jurnal Matriks Teknik Sipil/ September 2017/766

Kustiani, I. Et al. 2016. Analiis Time Cost Trade Off Untuk Mengejar Keterlambatan Pelaksanaan Proyek Di Bandar Lampung. Jurnal Rekayasa, Vol. 20, No. 2, Agustus 2016

Mela, A.F. 2016. analisis time cost trade off untuk mengejar keterlambatan pelaksanaan proyek Study kasus: pembangunan hotel Zodiak Lampung, Pembangunan hotel park in by radisson, pembangunan toko Mitra hasil sentosa di bandar lampung. Skripsi. Program Pascasarjana Universitas Lampung. Bandar Lampung

Priyo, M. dan A. Sumanto. 2016. Analisis Percepatan Waktu dan Biaya Proyek Konstruksi Dengan Penambahan Jam Kerja (Lembur) Menggunakan Metode Time Cost Trade Off: Study Kasus Proyek Pembangunan Prasarana Pengendali
Banjir. Jurnal Ilmiah Semesta Teknika Vol 19, No. 1, 1-15, Mei 2016

Simatupang, J.S. et al. 2015. Pengaruh percepatan durasi terhadap waktu pada proyek konstruksi (study kasus: Pembangunan persekolahan Eben Haezar Manado). Jurnal Sipil Statik Vol. 3 No. 5 Mei 2015 (281-280) ISSN: 2337-6732

Taufik, H. dan Jurandi. 2017. Analisis Percepatan Terhadap Biaya Proyek (Study Kasus: Kantor Dinas SKPD Gedung B5 Tenayan Raya). Jom FTEKNIK Volume 4 No. 2 Oktober 2017 